\title{
From outsiders to insiders? Strategies and practices of American film distributors in post-war Italy
}

Article

Accepted Version

Miskell, P. and Nicoli, M. (2016) From outsiders to insiders? Strategies and practices of American film distributors in postwar Italy. Enterprise and Society, 17 (3). pp. 546-590. ISSN 1467-2235 doi: https://doi.org/10.1017/eso.2015.86 Available at https://centaur.reading.ac.uk/42596/

It is advisable to refer to the publisher's version if you intend to cite from the work. See Guidance on citing.

To link to this article DOI: http://dx.doi.org/10.1017/eso.2015.86

Publisher: Cambridge University Press

All outputs in CentAUR are protected by Intellectual Property Rights law, including copyright law. Copyright and IPR is retained by the creators or other copyright holders. Terms and conditions for use of this material are defined in the End User Agreement.

www.reading.ac.uk/centaur 
Central Archive at the University of Reading

Reading's research outputs online 


\section{From outsiders to insiders? Strategies and practices of American film distributors in post-war Italy}

This article examines the impact of structural changes in the post-war film industry on the activities and effectiveness of the foreign distribution subsidiaries of American firms. As these subsidiaries saw their regular supply of films from their in-house Hollywood studios decline, they sought out alternative sources of product content, often from local markets. Unable to rely on the traditional 'ownership' advantages bestowed on them by their parent firms, these subsidiaries increasingly needed to integrate into local networks and forge closer relationships with local producers and exhibitors. Our focus is on Italy, one of the most important film markets for US companies in the 1960s. We collect data on the box-office revenues and screen time allocated to every film released into the $1^{\text {st }}$ run cinema market, and compare the effectiveness of American versus Italian distributors in maximising the exposure of their most popular films. We explore the attempts by US firms to form partnerships with Italian distributors and producers. Finally, we examine available archival records to reveal the detailed activities of US distribution offices in Italy, and their attempts to integrate into local business networks. We conclude that while US subsidiaries did not fully succeed in becoming 'insiders' within the Italian film industry in this period, they did actively work toward such an objective.

Keywords: Business history; international business; subsidiary firms; liability of outsidership; motion picture industry; film distribution. 


\section{From outsiders to insiders? Strategies and practices of American film distributors in post-war Italy}

The question of how the foreign subsidiaries of multinational firms overcome the challenges of doing business abroad remains an important question for theorists and historians of international business. ${ }^{1}$ Do these subsidiaries rely on the 'ownership advantages' of their corporate parents to surmount their inherent foreignness; or do they seek to lessen (or disguise) their foreignness by becoming more deeply embedded in the local business environment? Do we find subsidiaries shifting from one strategy to the other as the competitive environment changes over time? This article focuses on the foreign distribution subsidiaries of major American film companies following the collapse of the socalled Hollywood studio system. The period was one which saw international distribution become increasingly important for US firms, yet the traditional advantage on which these foreign subsidiaries had relied (exclusive access to the output of in-house Hollywood film studios) was unravelling. How did foreign distribution subsidiaries respond to this situation?

The demise of the Hollywood studio system and the structural disintegration of the film industry in the 1950s and 1960s has attracted the interest of scholars from various academic disciplines. The industry has provided a case study of the shift from a classical 'Fordist' system of mass-production, in which manufacture, distribution and exhibition of films was controlled by an oligopoly of vertically integrated firms, to one based on flexible networks of small specialist firms who combined to produce and market individual films on a project-by-project basis. ${ }^{2}$ Whether this evolution involved the crossing of an 'industrial divide' has been a matter of contention, but its implications have been widely analysed and discussed. ${ }^{3}$ Economic geographers have examined the location of production activities, emphasising the continued dominance of the industrial cluster centred on Hollywood, while identifying concentrations of specialist firms elsewhere in pre- or post-production services and activities. ${ }^{4}$ Economic historians have explored how film producers responded to the increasing levels of uncertainty in the post-war era, developing new strategies for the management of risk. ${ }^{5}$ Organisation theorists have identified the 'New Hollywood' as one of the most visible illustrations of the changing nature of the workplace, seeing the film industry as an exemplar of the emerging creative economy. ${ }^{6}$ Historians of international business, however, have had relatively little to say about the film industry in the post-war decades, even though the period was one in which foreign markets grew in significance for the leading American firms. ${ }^{7}$

\footnotetext{
${ }^{1}$ Recent works include Bhanji and Oxley, "Overcoming the dual liability of foreignness and privateness"; Baik, Kang, Kim and Lee. "Liability of foreignness in international equity investments"; Lubinski, "Liability of foreignness in historical context".

2 Storper, "The transition to flexible specialisation"; Storper and Christopherson, "Flexible specialisation".

3 Askoy and Robins, "Hollywood for the $21^{\text {st }}$ century"; Storper, "A response"; Robins,

"Organization as strategy".

${ }^{4}$ Scott, "A new map of Hollywood"; Scott, "Hollywood and the world"; Scott, On Hollywood.

5 Sedgwick and Pokorny, "The risk environment of film making"; De Vany, Hollywood Economics.

${ }^{6}$ Florida, The Rise of the Creative Class; Howkins, The Creative Economy;

${ }^{7}$ Guback, The International Film Industry; Waterman, Hollywood's Road to Riches.
} 
At one level, this is understandable. Far from discovering the emergence of a new post-industrial era, historians of multinational enterprise point to the 1950s and 1960s as period in which FDI flows were dominated by large American manufacturing firms. ${ }^{8}$ As far as the growth of international business was concerned, the post-war decades look like the highpoint of the integrated Chandlerian firm. Even within the film industry it appeared, on the surface at least, as though the functioning of international firms remained largely unchanged in the post-war decades. The distribution arms of the major US film companies built global networks of subsidiaries in the 1920s and 1930s, and these remained largely intact throughout the 20th century. ${ }^{9} \mathrm{~A}$ closer examination of international film distribution in this period, however, reveals a more complex (and perhaps a more interesting) picture. While the presence of US-owned film distributors in international markets may not have changed very much in the 1950s and 60s, the functions performed by these subsidiaries, and the resources on which they depended, did begin to evolve very significantly. The break-up of vertical structures in the industry did, in fact, have very serious implications for the distribution subsidiaries of US firms, creating incentives for those subsidiaries to become more deeply embedded in their local markets.

The idea that foreign subsidiaries of multinational firms might need to be closely integrated into local business communities as well as the organisational network of their parent firm, is now well established within international business (IB) theory, though this was not always the case. ${ }^{10}$ The foundations of modern IB theory stem, at least in part, from attempts to understand the unprecedented growth of FDI flows from the United States to Western Europe in the post-war decades (which could not be explained by existing theories of capital investment). ${ }^{11}$ The emerging theory emphasised a clear distinction between 'direct' and 'portfolio' investments, with the former serving as the basis for multinational enterprises (MNEs) that owned and controlled value-adding activities in more than one country. ${ }^{12}$ Central to the new theory was the knowledge-base and strategic intent of parent firms. Thus FDI occurred when: firms were in possession of some particularly valuable knowledge, skills or resources; when they were able to identify a strategic opportunity to exploit this knowledge or resource in a particular foreign location; and finally when it was more beneficial to exploit these advantages through internal expansion than through licencing to local agents. ${ }^{13}$ The theory, which was developed and refined through the 1970s and 1980s, provided a logical explanation for global patterns of FDI in the second half of the twentieth century, but left little room for the agency of subsidiary firms. Theorists did recognise that foreign subsidiaries

\footnotetext{
8 Wilkins, The Maturing of Multinational Enterprise; Jones, Multinationals and Global Capitalism.

9 Thompson, Exporting Entertainment; Gomery, Hollywood Studio System.

${ }^{10}$ For a recent overview of the IB literature see Rugman et al. "Fifty years of international business theory".

${ }^{11}$ Kindleberger, American Business Abroad; Vernon, Sovereignty at Bay; Wilkins, Maturing of Multinational Enterprise.

${ }^{12}$ Hymer, The International Operations of National Firms.

13 These three factors formed the basis of the so-called eclectic paradigm. See Dunning, "Trade, location of economic activity and the MNEs"; Dunning, "The eclectic paradigm of international production".
} 
faced real challenges in competing against local rivals. Indeed, it was precisely because these subsidiaries faced a 'liability of foreignness' that they needed to posses a clear advantage over local rivals to remain competitive. ${ }^{14}$ Thus the key to success for foreign subsidiary companies (in early IB theory at least) was their ability to draw on the superior knowledge and resources of their parent firms. A subsidiary firm's embeddedness within the systems and structures of its parent firm may have made it 'foreign', but it also provided the necessary advantages to overcome this liability. Conceived this way, the 'foreignness' of overseas subsidiaries is unchanging, and their ability to integrate into local networks or acquire local knowledge is largely irrelevant. They live or die by the value of the firm-specific advantages bestowed by their parents. Such a view is not difficult to reconcile with the notion of MNEs as institutions that wield immense market power, and that the rapid expansion of US multinationals after 1945 marked the emergence of American hegemony. ${ }^{15}$

In recent decades historians interested in the idea of Americanisation, have sought to distance themselves from concepts such as American hegemony, preferring instead to highlight the role of local actors in (selectively) adopting American ideas and adapting them to particular local or national contexts. ${ }^{16}$ Similarly the IB literature, since the mid-1980s, has focussed increasing attention on the activities of subsidiary firms in adapting the knowledge and resources of their parents to local market needs. ${ }^{17}$ Scholars began to see the balance of global integration and local responsiveness as a key strategic challenge facing multinational firms. ${ }^{18}$ By the turn of the century, IB theorists were beginning to speak of 'competence creating subsidiaries', and it was becoming increasingly apparent that the success of foreign affiliates could be determined not just by their access to the firm-specific advantages of their parents, but also their integration into local business communities and access to local, market-specific knowledge. ${ }^{19}$ IB theorists now refer to the dual (or multiple) embeddedness of subsidiary firms. ${ }^{20}$

Alongside this re-assessment of the role of subsidiary companies, IB scholars have also sought to re-evaluate the concept of liability of foreignness. ${ }^{21}$ If subsidiaries can, over time, become embedded within local business networks

\footnotetext{
${ }^{14}$ Hymer, International Operations of National Firms; Zaheer, "Overcoming the liability of foreignness".

15 Stephen Hymer did in fact hold such a view, believing that MNEs were able to possess something close to monopoly power in foreign markets.

16 Zeitlin, Herrigel, Americanization and its Limits; Kipping, Bjarnar, The Americanisation of European Business; Djelic, Exporting the American Model; Bonin, de Goey, American Firms in Europe; Kuisel, Seducing the French; Kuisel, "Americanization for historians".

17 Bartlett, Ghoshal, "Tap your subsidiaries for global reach"; Hedlund, "The hypermodern MNC"; Abo, Hybrid Factory.

${ }_{18}$ Prahalad, Doz, The Multinational Mission; Bartlett, Ghoshal, Managing Across Borders.

${ }^{19}$ Birkinshaw, Hood, "Multinational subsidiary evolution"; Birkinshaw et al., "Building firm specific advantages"; Mudambi, Navarra, "Is knowledge power?"; Cantwell, Mudambi, "MNE competence-creating subsidiary mandates".

${ }^{20}$ Meyer et al., "Multinational enterprises and local contexts"; Narula, "Exploring the paradox of competence-creating subsidiaries".

21 Zaheer, "Overcoming the liability of foreignness"; Zaheer, Mosakowski, "The dynamics of the liability of foreignness"; Mezias, "Identifying liabilities of foreignness".
} 
does this mean that they are able to become less 'foreign'? Are firms from some countries more 'foreign' than others? Recent historical scholarship shows that in a given host market, foreign subsidiaries from different home countries could face very different challenges, with their country-of-origin viewed in either positive or negative terms, and that this was subject to change over time. ${ }^{22}$ Recently, IB theorists have helpfully started to conceptualise the challenge of doing business overseas less as a liability of foreignness than of 'outsidership'. ${ }^{23}$ Foreignness is a relatively crude and simplistic concept when examining subsidiary firms, as well as being something outside of their direct control. ${ }^{24}$ The extent to which subsidiaries are able to behave as insiders within a given foreign market, on the other hand, is potentially much more varied and complex. The conceptualisation around outsidership/insidership is helpful to our understanding of subsidiaries as multi-embedded enterprises. A subsidiary's embeddedness within its parent firm may enable it to overcome a liability of foreignness (as traditional IB theory explains), but if it becomes embedded in local business networks does its position begin to evolve from that of an outsider to one of increasing insidership? What are the circumstances under which subsidiary firms would be motivated to strive for insider status within a foreign market? How does such a process play out in practice?

The structural changes within the post-war film industry provide an excellent context in which to explore such questions. Here we have a case in which the foreign subsidiaries of US multinationals were incentivised to move from a system of single to multiple-embeddedness. We do not regard this to have been a natural or inevitable evolution, but rather the result of a very specific set of historical circumstances. This article explains the reason for this shift, and reveals some of the mechanisms by which subsidiaries sought to enhance their insider status. After outlining how the break-up of the studio system affected the basic structure of international film distribution, attention is focussed on Italy, which was an important cinema market for at least two reasons. First, compared to markets such as the US, UK or Germany, competition from television and other leisure activities had a much smaller impact on cinema attendance in Italy in the $1950 \mathrm{~s}$ and $60 \mathrm{~s}^{25}$ While other national markets were in rapid decline the Italian film market continued to grow, becoming an increasingly important source of revenue for US distributors. ${ }^{26}$ Second, the period witnessed a resurgence in creativity within the Italian film industry, and something of a boom in domestic film production. ${ }^{27}$ Here, then, we have one of Hollywood's largest foreign markets, but also a vibrant domestic film industry where US distributors faced no shortage of local competition.

We draw on both quantitative and qualitative data to make our case. Our most important source of statistical evidence is a newly constructed dataset, based on

\footnotetext{
${ }^{22}$ Lubinski, "Liability of foreignness in historical context".

${ }^{23}$ Johanson, Vahlne, "The Uppsala Internationalisation process model revisited".

24 Stevens, Shenkar, "The liability of home".

25 Forbes, Street, European Cinema, p. 21.

${ }^{26}$ Quaglietti, Il cinema Italiano nel dopoguerra; Brunetta, "The long march of American cinema in Italy".

27 Bondanella, Italian Cinema; Brunetta, The History of Italian Cinema.
} 
information held in the Borsa Film, an official trade publication - sponsored by the national association of exhibitors - which contains details of the box office revenues generated by, and the screen time allocated to, every film released into the Italian first-run market between cinema seasons 1957-8 and 1970-1. Borsa also records the distributor of each film, as well as its director and leading actors. To this data we have added information on the producers of each film, drawn from the Internet Movie Database (IMDb). The creation of this dataset enables us to assess the performance of different film distributors in Italy. Specifically, it allows us to compare the effectiveness of American and Italian distributors, as well as that of Italian-American joint ventures, in terms of their ability to maximise the screen time allocated to their most popular films. Was it the case, for example, that local distributors were able to secure more exposure for their films in prime cinema locations than foreign rivals? The quantitative data, in other words, allows us to measure the liability of outsidership faced by US subsidiaries, and whether the formation of local joint ventures helped to overcome this. The statistical evidence, however, can only take us so far. It indicates that while US firms may have had incentives to engage in local distribution partnerships, the advantages of such partnerships for Italian companies were much less apparent. Very few distribution joint ventures were actually sustained for more than a few years. For US-owned subsidiaries in Italy, if insidership could not be achieved through the creation of local partnerships it would need to be built up through the knowledge and connections of local managers. To examine how this was attempted we turn to the archives of one of the leading US distributors, Warner Bros. We scrutinise the records of Warner's Italian distribution subsidiary, and its correspondence with the corporate head office, to uncover the activities, contacts and relationships being pursued by the firm's Italian management. Having twice tried (and failed) in the early 1960s to form distribution partnerships with local firms, how did this particular American subsidiary company seek to enhance its insider status in the Italian market?

\section{US film distributors and their international markets}

US film companies could make a stronger claim than most multinationals to the status of truly global organisations in the mid-twentieth century. Writing in the Harvard Business Review in 1930 William Victor Strauss confidently declared that "there are few American industries that are more dependent upon foreign markets than the motion picture industry; and there are still fewer industries in which American dominance of world markets has, in the past, been more dramatic and complete." 28 In the period covered here markets outside of the US and Canada typically accounted for well over half of total sales, with the majority of this foreign revenue coming from Europe. ${ }^{29}$ The influence of Hollywood in Europe is a topic that has attracted much attention from historians, although the influence of Europe on the strategy and practices of US films distributors is less well understood. ${ }^{30}$ Studies of cinema audiences and the reception of films in Europe have pointed to the popularity of domestic films, and argued that the

\footnotetext{
28 Strauss, "Foreign Distribution of American Motion Pictures".

${ }^{29}$ Guback, The International Film Industry, 3.

${ }^{30}$ Ellwood, Kroes, Hollywood in Europe; Saunders, Hollywood in Berlin; Higson, Maltby, "Film Europe" and "Film America"; de Grazia, "Mass Culture and Sovereignty: The American Challenge to European Cinemas, 1920-1960".
} 
Hollywood films with the greatest appeal were usually those with themes or stars to whom domestic audiences could most easily relate. ${ }^{31}$ Such research suggests that US film distributors would have had a clear incentive to adapt their film portfolios to the particular preferences of their main international markets, yet little work has been done to examine whether the subsidiaries of US film multinationals did in fact attempt to do this. ${ }^{32}$ Much of the existing work which does look at Hollywood and its foreign markets, focuses extensively on film policy, and in particular on the role of the Motion Picture Export Association (MPEA) in pressuring foreign governments to ease restrictions on the imports of American films. ${ }^{33}$ While this work demonstrates that the MPEA, and its predecessor the Motion Picture Producers and Distributors of America (MPPDA), did undeniably play an important role in facilitating the export of Hollywood entertainment, there is a danger that by overemphasising their role in shaping film policy we too easily begin to treat "Hollywood" as a homogenous entity, whose primary function was to support US foreign policy objectives. From the perspective of IB theory, this literature focuses almost exclusively on the country-specific advantages enjoyed by US companies, but fails to explore their firm-specific characteristics. The major US film companies did indeed collaborate under the banner of the MPEA in order to press for common political objectives, but when it came to managing their business operations in specific markets, the firms were competitors and often pursued quite distinct business strategies. ${ }^{34}$ This article focuses attention not just at the firm level, but at that of the foreign subsidiary. Before examining the activities and performance of subsidiary firms, however, we should introduce their parents.

The transformation of the US film industry in the 1950s and 1960s was triggered by declining cinema audiences in the face of competition from television, and the requirement that firms sell-off their domestic cinema chains in compliance with anti-trust legislation in the form of the Paramount decree of 1948. ${ }^{35}$ The period witnessed the disintegration of industry structures, with the so-called major 'studios' relinquishing direct ownership and control over both cinema exhibition, and the vast majority of Hollywood film production. ${ }^{36}$ Yet as far as film distribution was concerned, continuity was at least as evident as change. ${ }^{37} \mathrm{With}$ the exception of RKO, which withdrew from film production and distribution in 1957, the oligopoly of US firms which had emerged to dominate global film distribution in the 1920 s remained intact. ${ }^{38}$ During the 1930 s and 1940 s a

\footnotetext{
${ }^{31}$ Garncarz, "Hollywood in Germany: the role of American films in Germany, 1925-1990", in Hollywood in Europe, eds. Ellwood, Kroes, 107-9; Glancy, When Hollywood Loved Britain; Stokes, Maltby, Hollywood Abroad; Fanchi, Mosconi, Forme di consumo; Casetti, Mosconi, Riti e ambienti; Spinazzola, Cinema e pubblico.

32 The best available study of the foreign distribution activities of US film companies remains Thompson, Exporting Entertainment, but this focuses primarily on the silent era.

33 Trumpbour, Selling Hollywood to the World; Jarvie, Hollywood's Overseas Campaign; Swann, "The Little State Department" in Hollywood in Europe, eds. Ellwood, Kroes; Segrave, American Films Abroad.

34 Miskell, "Resolving the Global Efficiency Versus Local Adaptability Dilemma"; Sedgwick et al.,

"Hollywood in the World Market".

${ }^{35}$ For a summary see Casper, Postwar Hollywood.

${ }^{36}$ Storper, "The Transition to Flexible Specialisation".

${ }^{37}$ Aksoy, Robins, "Hollywood for the $21^{\text {st }}$ Century".

38 Jewell, RKO Radio Pictures; Lasky, RKO.
} 
distinction could be drawn between the 'big five' film companies (MGM, Paramount, Twentieth Century Fox, Warner Bros. and RKO), and the 'little three' (Universal, Columbia and United Artists). ${ }^{39}$ The former group were characterised by their ownership of large domestic cinema chains in the US, and their extensive film production activities (typically 40-60 feature films per year). The 'little three' did not operate cinema chains, and if they engaged in film production at all, did so on a less ambitious scale than the larger vertically integrated firms. ${ }^{40}$ By the 1960s the distinction between 'big five' and 'little three' had largely dissolved. Film distribution (rather than production or exhibition) was now the primary activity of all the major firms. The post-war decades saw Universal, Columbia and United Artists grow in prominence, while the once mighty MGM (the leading film producer of the 1930s and 1940s) saw its market position gradually decline.

Each of these companies had built up an extensive global network of distribution offices in the 1920s and 1930s. ${ }^{41}$ While subsidiaries based in territories controlled by the axis powers were forced to close during the Second World War, the majority of these offices were re-opened soon after the end of hostilities, and by the mid-1950s the international reach of these distribution companies was wider than ever. ${ }^{42}$ The period under examination here was not one in which US film companies were expanding abroad for the first time. These were multinational enterprises with several decades of experience operating in overseas markets. In Europe, the key challenge they faced was not one of market entry, but of how to maintain competitiveness in diverse and rapidly evolving market environments. During the so-called studio era the task of distribution subsidiaries of the major US firms had essentially been to handle the local release of its parent's films. Ownership of the intellectual property rights to these pictures constituted the primary 'advantage' on which these subsidiaries traded. Moreover, the volume of films that US distribution subsidiaries were able to offer was highly valued by local exhibitors, particularly in second and third run markets, who required a high quantity of product (due to their practice of screening double-feature programmes which were typically replaced on a twice weekly basis). ${ }^{43}$ As vertical structures within the industry began to disintegrate, however, the supply of 'in-house' product began to run dry.

\footnotetext{
${ }^{39}$ Gomery, The Hollywood Studio System.

${ }^{40}$ Columbia and Universal were both producer-distributors, but United Artists specialised in film distribution only. Balio, United Artists.

41 Thompson, Exporting Entertainment.

42 The numbers of international distribution offices operated by each of these firms was recorded annually in the Film Daily Yearbook.

43 Sedgwick et al. "Hollywood in the world market".
} 
Table 1: Films in which MGM and Warner Bros. owned world-wide distribution rights, 1951-63

\begin{tabular}{|l|c|c|c|c|c|c|}
\hline & \multicolumn{2}{|c|}{ MGM } & \multicolumn{2}{c|}{ Warner Bros. } & \multicolumn{2}{c|}{ Combined } \\
\hline & $\begin{array}{l}\text { Studio } \\
\text { production }\end{array}$ & $\begin{array}{l}\text { Outside } \\
\text { producer }\end{array}$ & $\begin{array}{l}\text { Studio } \\
\text { production }\end{array}$ & $\begin{array}{l}\text { Outside } \\
\text { producer }\end{array}$ & $\begin{array}{l}\text { All film } \\
\text { releases }\end{array}$ & $\begin{array}{l}\text { \% studio } \\
\text { productions }\end{array}$ \\
\hline $1951 / 2$ & 41 & 0 & 20 & 7 & 68 & 90 \\
\hline $1952 / 3$ & 46 & 0 & 20 & 6 & 72 & 92 \\
\hline $1953 / 4$ & 28 & 0 & 14 & 11 & 53 & 79 \\
\hline $1954 / 5$ & 24 & 0 & 7 & 12 & 43 & 72 \\
\hline $1955 / 6$ & 20 & 3 & 12 & 12 & 47 & 68 \\
\hline $1956 / 7$ & 21 & 10 & 10 & 11 & 52 & 60 \\
\hline $1957 / 8$ & 10 & 22 & 9 & 17 & 58 & 47 \\
\hline $1958 / 9$ & 15 & 9 & 7 & 9 & 40 & 55 \\
\hline $1959 / 60$ & 15 & 5 & 7 & 11 & 38 & 58 \\
\hline $1960 / 1$ & 11 & 4 & 7 & 6 & 28 & 64 \\
\hline $1961 / 2$ & 10 & 6 & 8 & 8 & 32 & 56 \\
\hline $1962 / 3$ & 3 & 7 & 5 & 7 & 22 & 36 \\
\hline
\end{tabular}

Source: For MGM, the Eddie Mannix ledger, held at the Margaret Herrick Library of the Academy of Motion Picture Arts and Sciences; for Warner Bros., the William Schaefer ledger, held at the University of Southern California Film and Television Archives, Los Angeles.

The 1950s saw major film companies like MGM and Warner Bros. significantly reduce their volume of studio production. The distribution arms of these firms were thus required to source content from outside producers to make up some of this shortfall. By the 1960s it was clear that not only were the total number of films being released by leading US distributors in decline, but these distributors were increasingly reliant on external sources of supply. For the foreign distribution subsidiaries of US firms, this meant their long-standing source of competitive advantage (exclusive rights to the films of their in-house Hollywood studio) was beginning to look precarious. Even if the rights to distribute a certain proportion of independently produced Hollywood films could be secured, their supply of American films remained on a downward trajectory.

Fig. 1a: Film distribution in the studio era

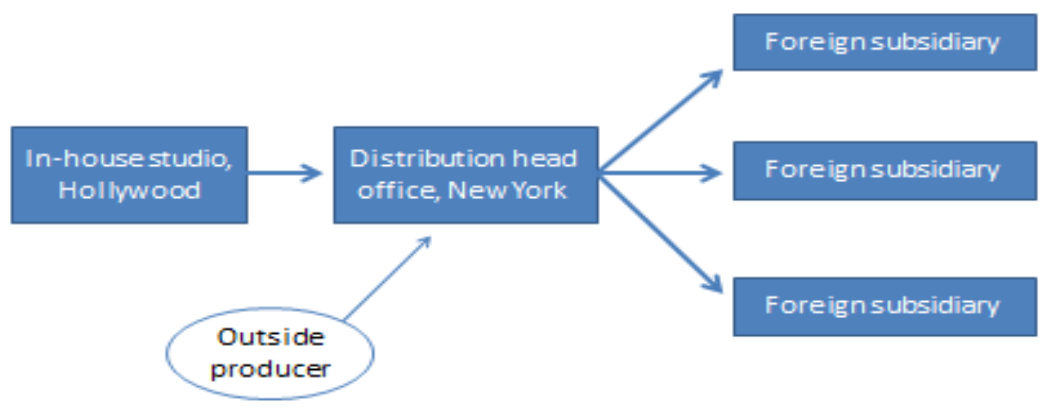


Fig. 1b: Film distribution in the post studio era

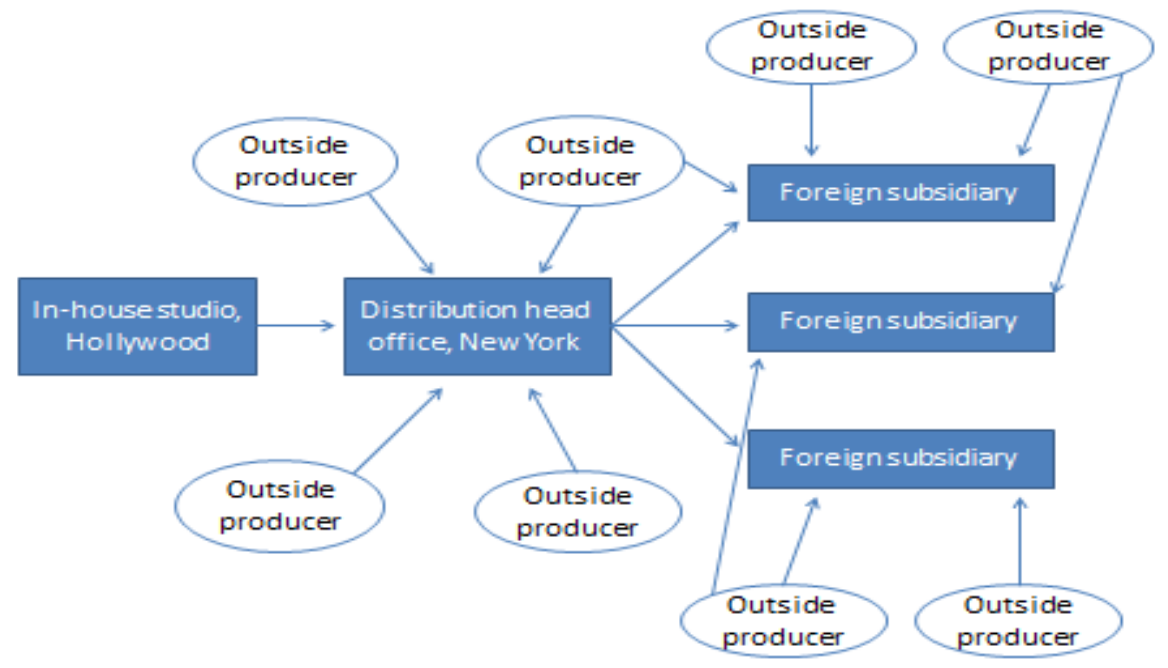

Increasingly, foreign distribution offices of US firms were required to source local content to meet the needs of local audiences. Nowhere was this more apparent than in Italy.

\section{The market for film in 1960s Italy}

Between the mid-1950s and the early 1970s Italy's economy grew by an average of 5.6 per cent each year - a faster rate of growth than (almost) any other European country. ${ }^{44}$ This so-called economic miracle enabled Italy to effectively catch-up with the most advanced industrial economies. ${ }^{45}$ Investment in US-style mass-production technologies under the Marshall Plan, and the opening up of intra-European trade within the European Economic Community (of which Italy was a founding member) opened up opportunities for export-led growth. ${ }^{46}$ The system of fixed exchange rates and capital controls agreed at Bretton Woods meant that the Lire remained highly competitive and the export-led boom could be sustained, which in turn encouraged further investment in technology and improved productivity. ${ }^{47}$ Italy was thus able to take maximum economic advantage of comparatively low labour costs as well as cheap energy. Growth was most pronounced in industrial sectors such as engineering, chemicals and

\footnotetext{
${ }^{44}$ Colli, "Investing in a Developing Economy", in American Firms in Europe, eds. Bonin, de Goey, 140; Petri, Storia economica d'Italia; Barca, Storia del capitalismo italiano; Pellegrini, "Lo sviluppo strutturale dell'economia italiana”, in Storia economica d'Italia, eds. Ciocca and Toniolo; Crainz, Storia del miracolo italiano. Culture, identità, trasformazioni fra anni cinquanta e sessanta; ID., Il paese mancato. Dal miracolo economico agli anni ottanta; Castronovo, Storia economica d'Italia. Dall'Ottocento ai giorni nostri, 410-17; Van der Wee, L'economia mondiale tra crisi e benessere (1945-1980); Lanaro, Storia dell'Italia repubblicana; Bocca, Miracolo all'italiana; Gorgolini, L'Italia in movimento. Storia sociale degli anni Cinquanta; Morcellini, De Nardis, Società industria culturale in Italia; Cardini, Il miracolo economico italiano 1958-1963; Foot, Milano dopo il miracolo: biografia di una città; Castronovo, L'Italia del miracolo economico; Belcampo, L'Italia entra nel miracolo economico in bicicletta e ne esce in automobile; Balduini, Miracoli e boom. L'Italia dal dopoguerra al boom economico nell'opera di Cesare Zavattini; Mafai, Il sorpasso: gli straordinari anni del miracolo economico 1958-1963.

45 Felice, Vecchi, "Italy's Modern Economic Growth".

46 Pistoresi, Rinaldi, "Exports, Imports and Growth".

47 Barbiellini Amidei, Cantwell and Spadavecchia, "Innovation and Foreign Technology".
} 
metals, often led by State-owned organisations, with relatively few large-scale private enterprises (such as auto-maker Fiat) coming to the fore. ${ }^{48}$ The fruits of Italy's rapidly expanding GDP were not lost on workers and consumers. Net national income almost doubled in real terms from around 17,000 billion Lire in the mid-1950s to 30,000 billion in the mid-1960s. The same period saw net income per capita grow from 350,000 to 571,000 Lire. Agricultural employment dropped while employees in manufacturing industries rose from 32 to $40 \%$ and in the service sector from 28 to $35 \% .{ }^{49}$ An increasingly affluent industrial workforce found itself with more money to spend, and a greater range of consumption choices in their leisure time. Activities such as Sunday trips in the iconic Fiat 500 became not just possible, but widely popular. One contemporary novelist was able to write of the early 1960s as an "unexpected belle époque",50 while later historians have charted a process in which Italians adopted the "models and myths of capitalistic consumerism". ${ }^{51}$ Cinematically, these developments were captured in films such as Fellini's La Dolce Vita / The Sweet Life (1960), as well as a range of comedies which drew on the rapidly evolving social and economic landscape as a source of humour. ${ }^{52}$

Notwithstanding the advent of TV broadcasting, 53 in Italy, unlike many other European economies, the cinema industry was a beneficiary of this economic growth. ${ }^{54}$ Whereas rates of cinema attendance (and numbers of cinemas) were in steep decline in the US, UK and Germany by the 1960s, the Italian market remained remarkably buoyant. ${ }^{55}$ Cinema-going as a social activity had become deeply embedded in cities such as Rome in the $1950 \mathrm{~s},{ }^{56}$ and it continued to exert a strong appeal throughout the 1960s, especially among younger audiences. ${ }^{57}$ The peak year for film admissions in Italy was 1955 (compared to 1946 in both the US and the UK), and attendances did not drop back down to their 1950 level until 1966. The number of cinemas remained fairly stable from the late 1950s through the $1960 \mathrm{~s}$ at around 11,000 to $12,000.58$ The total number of screening days at Italian cinemas grew throughout the 1950s (peaking in 1962), and screen

\footnotetext{
48 Felice, Vecchi, "Italy's Modern Economic Growth”.

49 Istat, Sommario di statistiche storiche 1926-1985, 153; D'Apice, L'arcipelago dei consumi.

Consumi e redditi delle famigle in Italia dal dopoguerra ad oggi, 103. Figures are computed at 1963 constant prices.

${ }^{50}$ Calvino, "La belle époque inattesa”, in Tempi moderni, July-September 1961, 26.

51 Gundle, Communism and Cultural Change in Postwar Italy; ID., "L'americanizzazione del quotidiano. Televisione e consumismo nell'Italia degli anni Cinquanta".

52 Brunetta, The History of Italian Cinema; Lanzoni, Comedy Italian Style.

53 Grasso, Storia della televisione italiana.

${ }^{54}$ Gennari, Post-War Italian Cinema, 6-8; Brunetta, Storia del cinema italiano, Vol. 3, 6-12; Corsi, Con qualche dollaro in meno, 37-42. Luzzatto Fegiz, Il volto sconosciuto dell'Italia, 21; Diena, Gli uomini e le masse, 88.

55 Lev, The Euro-American Cinema, 18-19; Williams, European Media Studies, 81-2; Canosa, "Il nostro cinema alla riscossa" and "I film difficili fanno cassetta", both in Il Giorno, respectively November 28, 1959 and November 7, 1960. Bianchi, "Non è effimera l'espansione del nostro cinema", in Il Giorno, December 31 1961.

56 Gennari, Sedgwick, "Memories in Context".

57 Luzzatto Fegiz, Il volto sconosciuto.

58 This figure refers to commercial cinemas only. According to a detailed MPAA report there were 11,148 'motion picture theatres' in Italy in 1957, as well as 5,955 parish halls that were also used for screening films. A. Manson, "Survey of the Italian Motion Picture Market", October 1958, Box 16520A, Warner Bros. Archive [WBA hereafter]. See also Wagstaff, Italian Neorealist Cinema, 417.
} 
days remained 20 per cent higher in 1971 than they had been in 1950 . The enduring appeal of cinema entertainment, combined with admission prices that rose faster than the rate of inflation, meant that box office revenues continued to grow throughout the period. At current prices, expenditure on cinema entertainment grew by 87 per cent between 1958 and 1971. At constant prices the figure stands at 19 per cent.

Table 2: Cinema admissions, expenditures and screening days in Italy, 1950-1971

$\begin{array}{llllll}\text { Year } & \text { Total } & \text { No. of } & \text { Average } & \text { Expenditure } & \text { Expenditure } \\ \text { screening } & \begin{array}{l}\text { tickets } \\ \text { days }\end{array} & \text { sold } & \text { (lire) } & \text { (lire 000s) } & \text { (lire 000s) } \\ & \text { sold } & & \end{array}$

(000s)

\begin{tabular}{lrrrrr} 
& & & & Nominal & \multicolumn{1}{l}{$\begin{array}{l}\text { At } 1957 \\
\text { prices }\end{array}$} \\
1950 & $1,509,020$ & 661,549 & 96 & $63,404,220$ & $83,503,358$ \\
1951 & $1,616,137$ & 705,666 & 104 & $73,203,418$ & $87,917,305$ \\
1952 & $1,735,715$ & 748,099 & 112 & $83,672,172$ & $96,390,342$ \\
1953 & $1,844,546$ & 777,910 & 121 & $94,501,722$ & $106,786,946$ \\
1954 & $1,927,345$ & 800,733 & 131 & $105,172,148$ & $115,689,363$ \\
1955 & $2,009,362$ & 819,424 & 142 & $116,690,729$ & $124,859,080$ \\
1956 & $2,039,734$ & 790,153 & 147 & $116,021,155$ & $118,225,557$ \\
1957 & $2,028,827$ & 758,364 & 149 & $112,780,786$ & $112,780,786$ \\
1958 & $2,029,532$ & 730,412 & 152 & $110,774,095$ & $105,700,472$ \\
1959 & $2,039,337$ & 747,904 & 156 & $116,639,557$ & $111,723,714$ \\
1960 & $2,037,144$ & 744,781 & 162 & $120,986,712$ & $112,966,118$ \\
1961 & $2,070,096$ & 741,019 & 170 & $125,650,146$ & $113,916,723$ \\
1962 & $2,075,573$ & 728,572 & 182 & $132,470,984$ & $114,297,657$ \\
1963 & $2,035,169$ & 697,480 & 201 & $140,517,638$ & $111,877,100$ \\
1964 & $2,058,942$ & 682,985 & 221 & $151,099,011$ & $114,468,948$ \\
1965 & $2,031,672$ & 663,080 & 240 & $159,079,787$ & $115,526,352$ \\
1966 & $2,001,438$ & 631,957 & 262 & $165,305,675$ & $117,655,285$ \\
1967 & $1,929,429$ & 568,926 & 289 & $164,265,188$ & $114,630,278$ \\
1968 & $1,881,569$ & 559,933 & 305 & $170,617,802$ & $117,586,356$ \\
1969 & $1,868,308$ & 550,884 & 325 & $179,209,690$ & $120,113,733$ \\
1970 & $1,831,793$ & 525,006 & 346 & $181,896,364$ & $116,005,334$ \\
1971 & $1,814,272$ & 535,733 & 386 & $206,814,843$ & $125,646,928$
\end{tabular}

Source: "Lo Spettacolo in Italia", Società Italiana Autori Editori (SIAE) Roma, annual publication.

As well as being a growing market, Italy was also a relatively unrestricted one for American film distributors. ${ }^{59}$ The Italian-American Film Agreement, originally signed in 1951,60 did place a limit on the number of American pictures that US distributors could release annually in Italy, but the figure was set at a sufficiently high level that the major US companies were not prevented from handling the distribution of their own productions in Italy. There was no limit imposed on the number of American films that could be released by Italian distributors. In 1962 the film quota was dropped entirely, leading the American trade press to report

\footnotetext{
${ }^{59}$ Gennari, Post-War Italian Cinema.

${ }^{60}$ ANICA, Venti anni dell'ANICA, 12-14; Quaglietti, Storia economico-politica.
} 
that "according to the [Motion Picture Export] Association, the new agreement assures virtually a free market for United States films in Italy."61

These trends meant that Italy became an increasingly important market for the major US film distributors in the post-war decades. In the 1930s and 1940s the UK dwarfed all other foreign markets as far as the Hollywood studios were concerned, with around half of all foreign revenues derived from there. ${ }^{62}$ By the early 1960s Italy was not only Hollywood's largest non-English language foreign market, it was almost equal to the British one in terms of the revenues it generated for US distributors. ${ }^{63}$

If the Italian market became an increasingly attractive location for US film companies in the 1960s, it was also one that was becoming increasingly competitive. As Hollywood studios scaled back production in response to declining audiences at home and in other parts of the English speaking world, Italian film production blossomed.64 In 1958 the output of Italian film production companies was 141 pictures, but by 1972 (the peak year) this figure had doubled to 280. This contrasted with a decline in the numbers of American films being distributed in Italy from 233 in 1958 to 127 in $1967 .{ }^{65}$ Film historians tend to agree that it was not just the volume of Italian film production that was increasing in this period, but also its quality. ${ }^{66}$ Directors such as Rossellini, Fellini, Di Sica, Visconti and Leone attracted international acclaim while stars such as Sophia Loren and Marcello Mastroianni achieved success in both Europe and America. ${ }^{67}$ While film-makers of the immediate post-war years had achieved international critical acclaim for neo-realist classics such as Roma Citta Aperta / Rome, Open City (1945) and Ladri di Biciclette / Bicycle Thieves (1948), by the mid-1950s the focus of Italian cinema had shifted from 'films of the people' to 'films for the people.' The 1960s witnessed the emergence of popular genres such as the spaghetti western, which appealed to international audiences as well as domestic ones, as well as the establishment of a lasting tradition of commedia all'italiana which provided the basis for some of the best loved films of the day and has remained popular in Italy ever since. ${ }^{68}$ As Peter Bondanella argues, "the decade between 1958 and 1968 may in retrospect be accurately described as the golden age of Italian cinema, for in no other single period was its artistic quality,

\footnotetext{
61 Film Daily Yearbook (January 1963): 590.

62 Miskell, "Selling America to the World'?"

${ }^{63}$ Aggregated data from four of the leading US distributors (Warner Bros., MGM, Paramount and Universal) show that Italy contributed 13 per cent of foreign revenue in 1961, while the UK and Ireland contributed 14 percent. The next most important markets were Germany (11\%), France (7\%) and Japan (6\%). Warner Bros. Archives [WBA hereafter], USC School of Cinematic Arts, Box 13116B, 'Comparison film billings', and Box 16591B, 'O'Sullivan miscellaneous - schedules of cost'.

${ }^{64}$ Brunetta, Storia del cinema italiano.

65 Bondanella, Italian Cinema, 142-144.

${ }^{66}$ Nowell-Smith, Making Waves, 152-162; Wood, Italian Cinema, 14-21; Sorlin, Italian National Cinema, 115-143.

67 Small, Sophia Loren; Reich, Beyond the Latin Lover; Burke, Valler, Federico Fellini; Wagstaff, "Italian Genre Films", in Hollywood and Europe, eds. Nowell-Smith, Ricci, eds., 74-85.

${ }^{68}$ Wagstaff, "A Forkful of Westerns", in Popular European Cinema, eds. Dyer and Vincendeau; D'Amico, La commedia all'italiana; Grande, La commedia all'italiana; Pintus, La commedia all'italiana.
} 
its international prestige, or its economic strength so consistently high." 69 Gian Piero Brunetta identifies the emergence of an "Italian style" in the post-war period which "would help to shape international cinema, influencing directors like Scorsese, Coppola, Ivory and Campion."70 The Italian film market may have become increasingly important for the major US film distributors by the 1960s, but it was a market in which Hollywood films were far from dominant. American pictures accounted for over half of all box office revenues in Italy in 1958 (with Italian films earning just over 30 per cent of the total). Yet by 1972 the share of box office earned by US films had dropped to little more than 15 per cent, while Italian productions (or co-productions) held over 60 per cent of the market. ${ }^{71}$

The figures commonly cited in the secondary literature for the numbers of American and Italian films released into the market, and the share of box-office revenue they attracted, are consistent with the evidence from our dataset. The number of US films released into the first-run market, according to our data, fell from 326 in the 1957/8 season to 151 in 1970/71. Italian film releases over the same period grew from 140 to 210 per year. Figure 2 illustrates that the turnaround in market share held by US and Italian films was evident in first run cinema venues as well as the wider market. While our dataset only captures information on a proportion of the Italian film market in this period, there are good reasons to believe that this was a particularly important sector of the market that broadly reflected wider industry trends.

Figure 2: Market share of Italian and US films in the $1^{\text {st }}$ run market, 1957-71

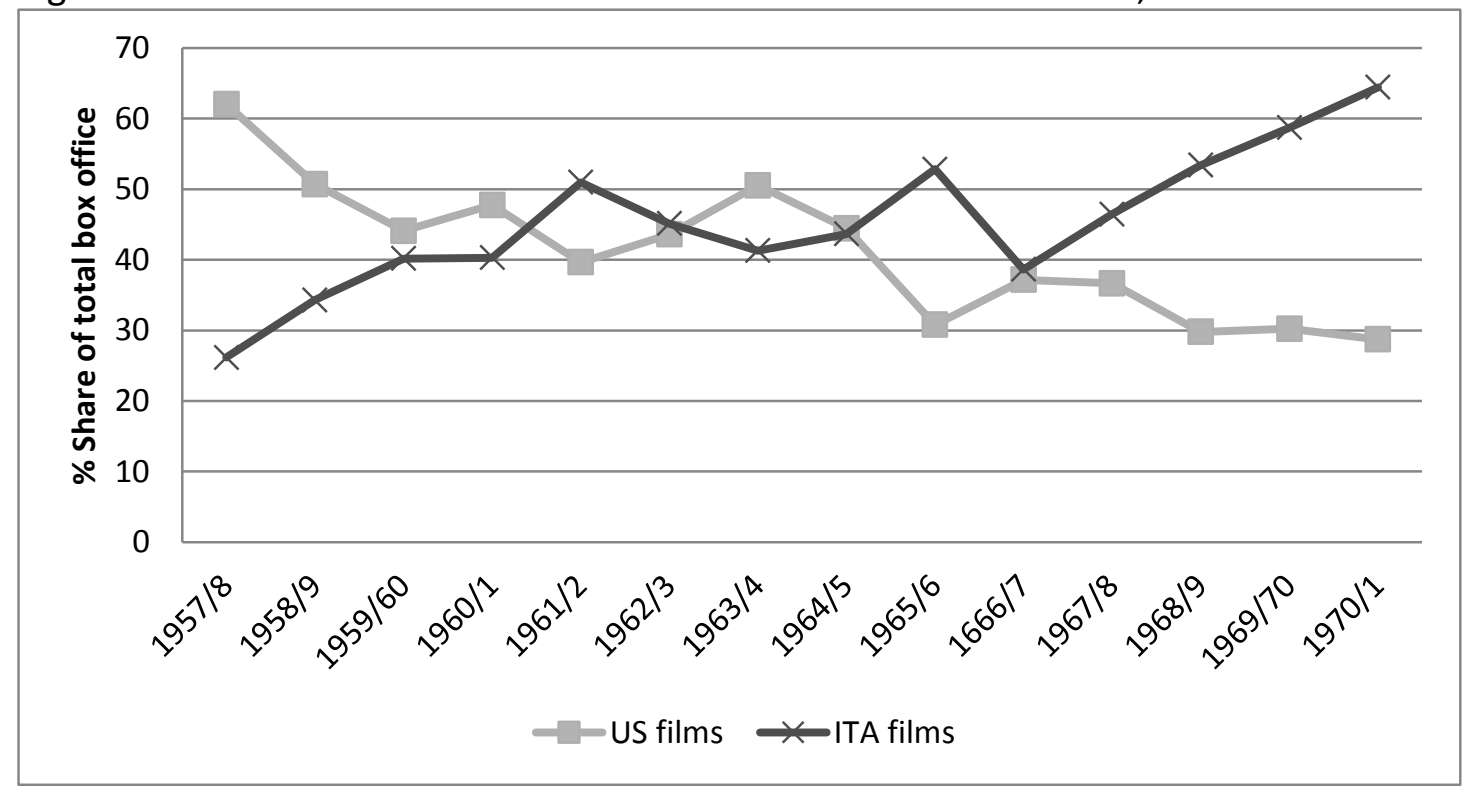

Source: Dataset

Did the growth in the share of the market held by Italian films simply reflect the increased number of such films being released, or were these domestic productions genuinely more popular than Hollywood movies? The question is not directly addressed in most surveys of the Italian film industry, yet it is crucial

${ }^{69}$ Bondanella, Italian Cinema, 142.

${ }^{70}$ Brunetta, The History of Italian Cinema, 10.

${ }^{71}$ Ibid., 143. 
if we are to understand the strategies of firms operating within this market. The information in our dataset on box-office earnings of each film allows us to compare the appeal of US and domestic productions for Italian audiences. (It should be noted that any co-productions involving Italian producers are classified here as Italian films, and similarly co-productions involving US companies are listed as American. There were a small number of US-Italian productions released throughout the period which have been classified separately. While these do not feature in the charts, they are discussed below.) Figure 3 shows that for much of the period under review the popularity of Italian and American films was broadly comparable. The shift in the overall share of the market towards Italian pictures (and away from Hollywood) was largely determined by the numbers of these films being released, rather than any decisive change in consumer preference for domestic product. Certainly, we can say that the sharp decline in market share held by US films in the late 1950s was almost entirely explained by the reduction in the number of Hollywood pictures being produced at the tail end of the studio system. Only towards the end of the period do we appear to see an emerging preference for Italian films (we are unable to say for how long this endured) and this explains the shift in market share towards domestic product towards the end of the 1960s. Among the most popular American films released in Italy during our period we find a preponderance of "sword-and-sandal" epics, such as The Bible / La Bibbla (John Huston, 1966), The Ten Commandments / I Dieci Comandamenti (Cecil B DeMille, 1956), Cleopatra (Joseph Mankiewicz, 1963), and Ben Hur (William Wyler, 1959). The most popular Italian releases included comedies Matrimonio All'Italiana / Marriage Italian Style (Vittorio De Sica, 1965), Per Grazia Ricevata / Between Miracles (Nino Manfredi, 1971), and Il Medico della Mutua / Be Sick... It's Free (Luigi Zampa, 1968), as well as Sergio Leone's Per Qualche Dollaro in Piu / For a Few Dollars More (1965) and Il Buono, Il Brutto, Il Cattivo / The Good, The Bad and the Ugly (1966). Fellini's La Dolce Vita / The Sweet Life (1960) was also among the ten most popular films released throughout the period.

Figure 3: Average box-office earnings of Italian and American films in the $1^{\text {st }}$ run market, 1957-71

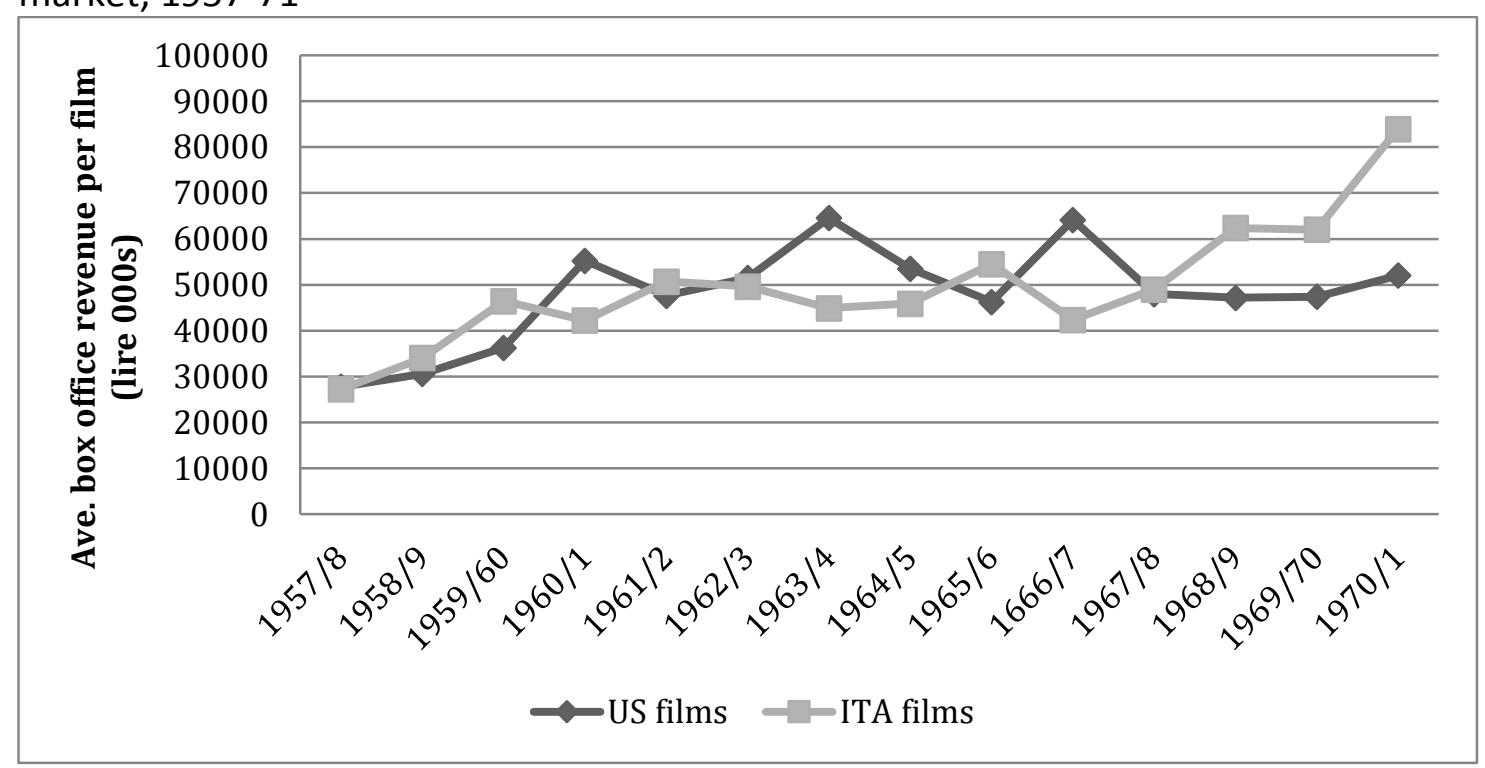

Source: Dataset 
If the popularity of American and Italian films was broadly comparable for most of our period, the same cannot be said for the small number of joint US/Italian productions released at this time. With only four or five such pictures typically released each year (and just one or two in some years) the average earnings of these films varied enormously from season to season. For the sixty US/Italian film releases throughout the period, however, average box-office revenues amounted to 106 million lire in the first run market, more than double the average revenues of either US or Italian pictures. Our dataset provides no information on the popularity of these films outside Italy, and of course worldwide revenue (and profit) performance would have been the yardstick by which producers judged the success or failure of such films. It is noticeable, however, that a number of these films, such Doctor Zhivago (prod. MGM / Carlo Ponti) and El Cid (prod. Samuel Bronston / Dear Film) were based on widely recognised stories or characters with a broad international appeal.

As far as US film distributors in the Italian market were concerned, we can clearly see that incentives existed for them to build and strengthen the local component of their product portfolios during this period. The declining numbers of US films being produced by the Hollywood studios meant that if they were to maintain their share of this growing market, US firms needed to secure distribution rights to more Italian pictures. The fact that Italian films were no less popular than Hollywood ones (and grew in popularity as the period progressed) would only have reinforced this need. Given the increasing reliance of US distribution subsidiaries on films made by outside producers, it was becoming increasingly important for these firms to demonstrate that they could operate as effectively as local competitors in promoting and marketing pictures in foreign markets. The distribution subsidiaries of US firms could no longer rely on the property rights to their parent company's films in order to overcome a traditional liability of foreignness. Establishing a position of insidership within major foreign markets such as Italy became increasingly important, both to secure distribution rights to popular local productions, and to maximise the screen time allocated to their releases. The information held in our dataset allows us to examine the effectiveness of US distributors in both regards.

\section{The system of film distribution and the effectiveness of US and Italian distributors}

Commercial film distribution in Italy in the post-war period was organised around sixteen cities, which acted as regional distribution centres. Cinema venues in each location fitted into a clear hierarchy with larger city centre "first run" theatres showing new releases, before films continued their distribution through second and third run cinemas. First run cinemas constituted about ten per cent of all cinemas in each of the sixteen centres, but as they were typically the largest venues charging the highest admission prices, they constituted much more than ten per cent of revenues. Moreover, without the marketing platform of a first run release, it was much harder for a film to secure bookings in the second and third run markets. Film distributors, therefore, had a very strong incentive to ensure that as many of their films as possible received a first run release. 
First run film distribution was clearly very important, but access to the first run market was also highly competitive. Not only were first run cinema venues relatively few in number, they also tended to book films for longer runs than was the case in second or third run halls. The purpose of first run distribution was to showcase the most prominent (and popular films) which might attract audiences from a broad geographic area, rather than to provide a regular local audience with reliable but ever changing stream of entertainment. As such, first run cinema venues required a smaller volume of product than second or third run halls, which meant that competition between distributors to secure first run bookings could be quite intense. In an era when US distributors held exclusive access to Hollywood entertainment, and these films faced relatively modest local competition, American firms held a powerful position vis-a-vis first run exhibitors. As local competition increased, and as their supply of in-house product declined, American subsidiaries found themselves needing to work much harder to secure prime first-run bookings for their films in the most important venues. No longer able to rely on exclusive access to the bulk of the most popular films, US distributor's subsidiaries needed to find ways of acquiring rights to popular local films, and of persuading local exhibitors to allocate valuable screen time to their releases. In this context the strength of a distributor's connections, and the depth of their relationships with local film producers and exhibitors became increasingly important. Previous studies have been unable to assess whether some distributors were more successful than others in securing access to first run cinema screens in Italy. The information in our dataset now makes this possible.

Up to now we have looked at aggregated data for very large numbers of films, but it is important to recognise that the distribution of box-office revenues was highly uneven, with a small number of 'hit' films capturing a large proportion of the total market. ${ }^{72}$ For film distributors what really mattered was not the typical performance of their median cinema release, but their ability to maximise the earning potential of their most popular 'hit' films. While the average box office revenue earned by the 6445 film releases in the first run market was 44 million lire (at 1957 prices), around two-thirds of these releases earned less than 30 million lire, and between them generated less than 16 per cent of total box office receipts. The top 6 per cent of releases, on the other hand, each earning at least 150 million lire, accounted for around 42 per cent of total revenues.

While it was not possible for firms to accurately predict, ex-ante, the extent of popular appeal for each picture, it was possible for them to secure extended screen time for hit films once the level of their popularity had been revealed within the first few days of release. In seeking to maximise the earning potential of their most popular films, the interests of distributors were eventually brought into conflict with first run cinema exhibitors. Both distributors and exhibitors benefited from the success of the most popular films, and both had an incentive to extend the runs of the very best performing films. The critical issue was how long should these runs be extended for? Demand to see even the most popular

\footnotetext{
72 This was a common feature of film distribution in most markets. See de Vany, Hollywood Economics.
} 
films diminished eventually, and as the number of screening days was extended, the revenue generated per day inevitably began to fall. For cinema exhibitors, there was a strong incentive to maintain daily takings at as high a level as possible. This meant that once demand for a film began to wane, it needed to be replaced quickly by a new picture that had the potential to earn more per day (even if only for a short time). Distributors, on the other hand, were primarily concerned to maximise the revenue (and the exposure) of their leading films in the first run market, and their incentive was to ensure that films were screened for as many days as possible until their demand had been virtually exhausted. By examining not just the box office revenues, but also the number of screen days allocated to each film in the first run market, we can see which types of distributors (and which types of film) were most successful in obtaining an extended cinema release.

We begin our investigation of this question by comparing the relationship between the box office revenues generated by, and the screen time allocated to, each film in our dataset. Unsurprisingly, we find a positive correlation between the two. We also find the relationship to be extremely strong. A simple correlation of box office revenue and screening days for all 6445 film releases in our dataset produces a positive coefficient of 0.95 . This reflects the fact that both distributors and exhibitors had a clear incentive to expand the supply of the most popular films in the market at the expense of less popular pictures, and that the system of distribution was effective in matching supply and demand. (One might argue, in fact, that box office revenue was actually a predictor of screen days rather than vice versa). Given the strong correlation between box office revenue and screen days, there is clearly only limited scope for the nationality of a film's distributor (or its producer) to influence the nature of this relationship. Wasn't it simply the case, therefore, that the most popular films were allocated the longest runs, irrespective of where those films came from? Well, yes, but only up to a point.

Figure 4: Screen time allocated to all film releases, by nationality of producer

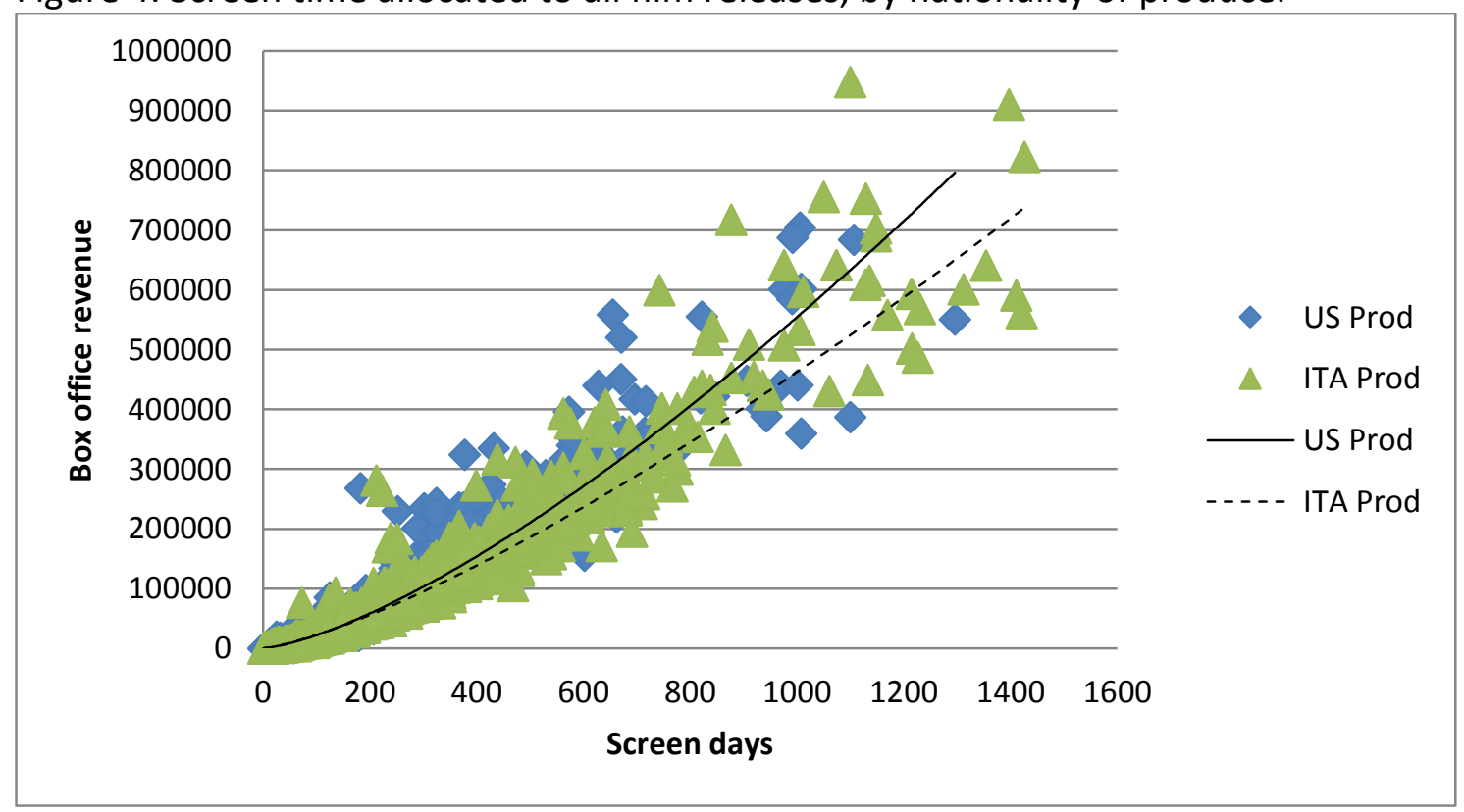

Source: Dataset 
Figure 4 plots the relationship between box office revenues and screen days for both Italian film releases and American pictures. As we would expect, there is a strong positive correlation in both cases (the R-squared figures are 0.95 and 0.96). Interestingly, however, we see that the line of best fit follows a slightly different path in each case. Among the less popular films it is almost impossible to identify any difference between US and Italian releases. Towards the top end of the revenue distribution, however, where we find the most popular hit films, it appears that exhibitors did show a preference for screening Italian pictures over American ones. Here the two lines on the chart begin to diverge. Why should first-run cinema exhibitors have prioritised the screening of Italian films over American ones? Wasn't it in their commercial interests to screen the most popular films, irrespective of their nationality? The explanation almost certainly lies in an incentive to book Italian films that exhibitors received in the form of a tax rebate. ${ }^{73}$ The MPEAA estimated the total value of this rebate to be worth 1.3 billion lire for all exhibitors in 1957. ${ }^{74}$ Tax breaks for exhibitors screening domestic films may well explain the discrepancy in screen time allocated to US and Italian films evidenced figure 4 . With this in mind we can now focus on a comparison of how film distributors of different nationalities performed in the Italian first-run market. Figure 5, below, compares the screen time allocated to the American film releases handled by different distributors, while figure 6 presents a similar comparison for Italian film releases. The trend lines shown in figures 5 and 6 each represent extremely strong relationships, with R squared values of between 0.95 and 0.98 in all cases.

Figure 5: Screen time allocated to US film releases, by nationality of distributor

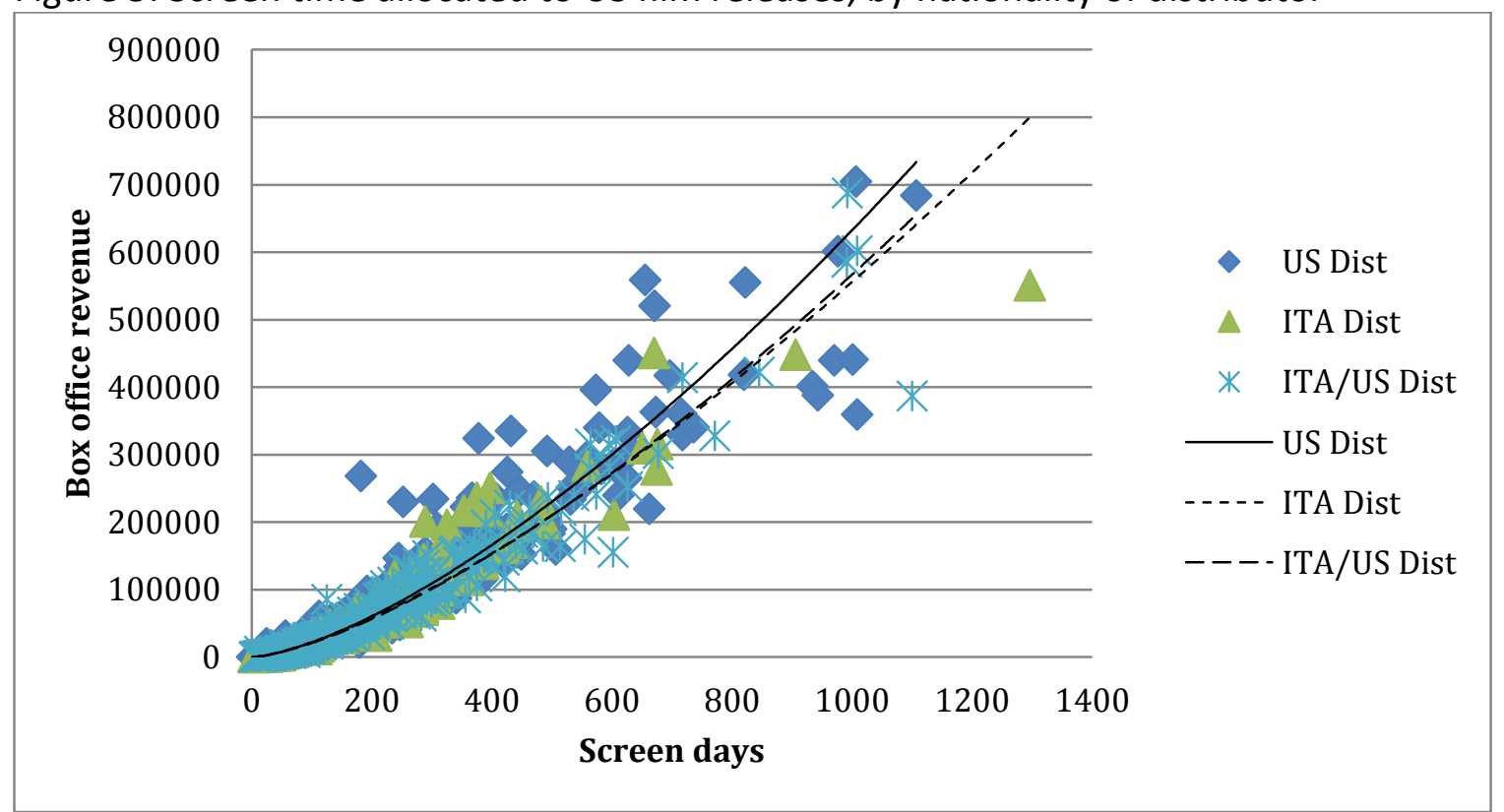

Source: Dataset

${ }^{73}$ Law n.448, Screen time quota, 29 December 1949; Law n.897, Screen time quota, 31 July 1956 and Law n.1213, New cinema order (Nuovo ordinamento dei provvedimenti a favore della cinematografia), 4 November 1965 . Tax rebate for exhibitors was equal to $20 \%$ of ticket levies in 1949 and 1956 laws and was reduced to 18\% of ticket levies in 1965. For discussion about these laws, see Quaglietti, Storia economico-politica del cinema italiano.

${ }^{74}$ A. Manson (on behalf of the MPEAA), Italy: Survey of the Motion Picture Market (October 1958), p.10. In "Italy Office" 16520A, WBA. 
The most striking feature of figure 5 is the apparent discrepancy between Italian and American distributors in terms of their ability to maximise screen time for their most popular Hollywood films. Once again, differences at the lower end of the revenue distribution are difficult to detect. For films which did not prove to be a hit with the public, access to the first-run market was quickly restricted, irrespective of their national origin, or that of their distributors. Among the most popular Hollywood releases, however, Italian distributors clearly appeared to be more successful than their US counterparts in extending the duration of first-run bookings. The biggest American hit films during our period were typically screened for more days in first-run venues if their distribution was handled by an Italian firm rather than a subsidiary of one of the US majors.

One possible explanation for the apparent preference shown by first run exhibitors to Italian distributors could be that US film renters demanded higher rental prices than their Italian counterparts. If this was the case then exhibitors would have had a clear financial incentive to prioritise the screening of films in which they retained a higher proportion of revenues. Such an explanation, however, is not plausible. Negotiations between exhibitors and distributors regarding the split of (post-tax) box-office revenue were tightly constrained by industry-wide agreements between the national trade bodies representing distributors (ANICA) and exhibitors (AGIS). US film distributors were members of ANICA, and were thus bound by the same rules governing film rental contracts as Italian firms. There would have been very little scope for US distributors to routinely demand higher rental prices than Italian firms. In fact, the AGIS-ANICA agreements allowed scope for renters to charge higher prices for Italian films, which would likely have benefitted Italian distributors more than American ones. ${ }^{75}$ The discrepancy between Italian and American distributors in terms of their ability to maximise the exposure of Hollywood films in the critical first-run markets, can be seen as evidence of a liability of outsidership. Domestic distributors, being more deeply embedded within local business networks and enjoying closer relationships with important cinema exhibitors, were better placed than foreign competitors to negotiate for extended first-run bookings for their most popular US films.

US/Italian distribution joint ventures (JVs) were also noticeably more successful than wholly-owned US subsidiaries in maximising the screen time of their top Hollywood pictures. Their performance in this regard was much closer to that of domestic Italian distributors than American ones. Like the wholly-owned US subsidiaries, the US/Italian JVs were heavily reliant on Hollywood product to fill their distribution portfolios. The joint ventures, however, enjoyed two important advantages. First, the extent of their dependence on Hollywood product was not as severe (21 per cent of films distributed by JVs were Italian, compared to just 12 per cent for US distributors). Second, the JVs were better able than US

\footnotetext{
75 The AGIS-ANICA agreement which ran until 30 June 1961 allowed distributors to charge a maximum rate of $50 \%$ of net receipts for outstanding films which were not to number more than a quarter of its total output. But in addition to this, the $50 \%$ rate could also be charged for a further three Italian films per season. MPEAA Country Fact Book: Italy, 29 December 1960, "Italy Office" 16520A, Warner Bros. Archive, University of Southern California School of Cinematic Arts (WBA hereafter).
} 
distributors to achieve extended first-run bookings for their most popular American films.

Figure 6: Screen time allocated to Italian film releases, by nationality of distributor

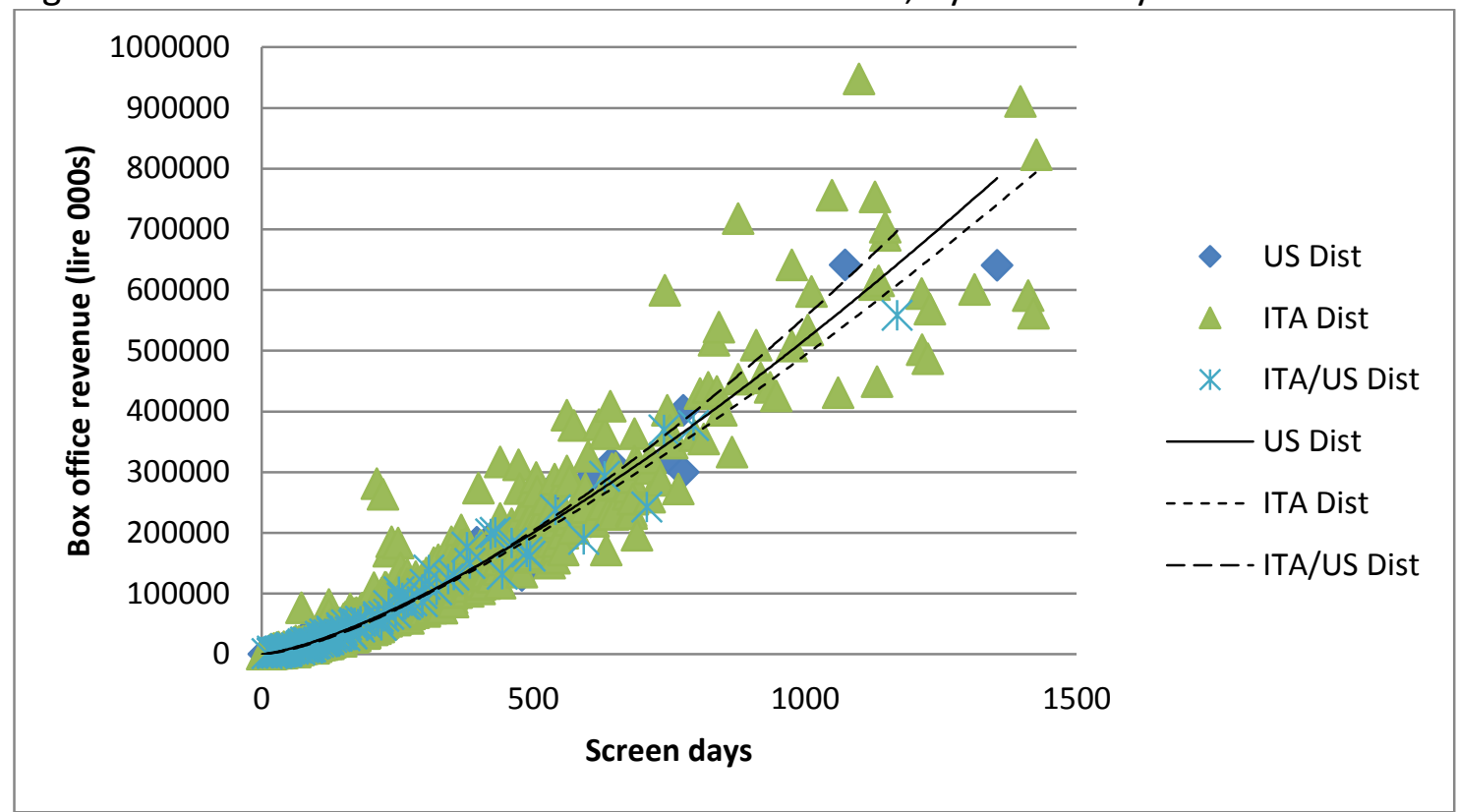

Source: Dataset

If differences between Italian and American firms were clearly evident in terms of the distribution of Hollywood pictures, such differences were less obvious when it came to the handling of Italian films. As figure 6 shows, Italian distributors were more effective than their American counterparts in maximising the screen time available to the most popular Italian films, but the difference was smaller than that depicted in figure 5. US/Italian joint ventures, meanwhile, appeared to be less effective than either US or domestic distributors in securing extended first-run bookings for Italian films (though with only 115 Italian films actually handled by JVs, and very few of these being hits, we are cautious about drawing firm conclusions about the performance of distribution JVs in this particular regard).

The evidence from figures 5 and 6 suggests that American distribution subsidiaries did face a liability of outsidership relative to domestic rivals, in terms of their ability to maximise the exposure of their most popular films in the first run market. The extent of this disadvantage was more pronounced in relation to Hollywood films than Italian ones. Acquiring the rights to more Italian films was one way in which US distributors could attempt to mitigate their liability. The establishment of a local distribution joint venture was another. Our evidence shows that US distributors were more successful in marketing their American films when working in partnership with a local firm. Perhaps as importantly, however, the creation of local distribution partnerships was a means by which US firms could attempt to increase their access to Italian content. 


\section{Working towards insider status: partnerships with local firms}

For American film companies seeking access to the increasingly important Italian market in the 1960s, there were advantages to be gained from establishing alliances with local distributors as well as from securing the rights to distribute high profile Italian films. Both of these approaches can be described as methods by which US firms became embedded within the domestic Italian market, drawing on local knowledge and connections in order to improve their operational effectiveness. In this section we examine the different strategies pursued by individual US companies as they sought to achieve such objectives.

The establishment of a joint venture with a local Italian distributor was perhaps the most obvious mechanism by which US firms could seek to improve their position within the Italian market. In the parlance of the international business literature, such a strategy allowed for the "bundling" of foreign and local assets. ${ }^{76}$ In this case US firms provided privileged access to the output of their in-house studio productions (as well as other films to which they held worldwide distribution rights), while the local Italian distributors could potentially provide improved access to the Italian first run market, as well as access to domestically produced films. As scholars of international business have pointed out, however, the decision to form an international joint venture is not something that multinational firms can make unilaterally. ${ }^{77}$ For multinationals to combine their resources with those of local firms, there also needs to be an incentive for local firms to engage in such an alliance. In the case of the Italian film industry, the incentive for US multinationals to seek out joint venture partners appeared to be stronger than the incentive for Italian distributors to partner with US firms. For US firms, the benefits of a joint venture included slightly improved access to Italian cinema screens for their own films, as well as potentially greater access to domestically produced films. For Italian firms however, the main benefits of any such alliance would have been the right to distribute more American films, but as we have seen, not only were the numbers of these declining in the 1960s, it was far from clear that Italian distributors would have gained anything by increasing the proportion of American pictures within their portfolios. This is reflected in the fact that only two Italian distributors were involved in joint ventures during our period (out of a total of 59 identified in our dataset), but four US firms (out of a total of just seven) embarked on such a strategy. Table 3 provides information on the firms involved, the timing of these alliances, and the numbers of films released.

\footnotetext{
${ }^{76}$ For example, Verbeke et al. 'New policy challenges for European multinationals' in New Policy, eds. Van Tulder et al.

77 Hennart, "Down with MNE-Centric Theories!".
} 
Table 3: Films distributed in Italy by Italian-American joint ventures, 1957-1970

\begin{tabular}{|c|c|c|c|c|c|}
\hline Year & Total films & $\begin{array}{l}\text { CEIAD- } \\
\text { Columbia }\end{array}$ & $\begin{array}{l}\text { Dear- } \\
\text { United } \\
\text { Artists } \\
\end{array}$ & Dear-Fox & $\begin{array}{l}\text { Dear-Int'l } \\
\text { Warner } \\
\text { Bros. }\end{array}$ \\
\hline 1957 & 43 & 43 & 0 & 0 & 0 \\
\hline 1958 & 32 & 32 & 0 & 0 & 0 \\
\hline 1959 & 26 & 26 & 0 & 0 & 0 \\
\hline 1960 & 25 & 25 & 0 & 0 & 0 \\
\hline 1961 & 26 & 26 & 0 & 0 & 0 \\
\hline 1962 & 28 & 20 & 4 & 4 & 0 \\
\hline 1963 & 75 & 25 & 28 & 22 & 0 \\
\hline 1964 & 65 & 19 & 22 & 24 & 0 \\
\hline 1965 & 71 & 26 & 23 & 22 & 0 \\
\hline 1966 & 78 & 29 & 27 & 22 & 0 \\
\hline 1967 & 79 & 25 & 31 & 23 & 0 \\
\hline 1968 & 67 & 25 & 38 & 0 & 4 \\
\hline 1969 & 68 & 18 & 31 & 0 & 19 \\
\hline 1970 & 46 & 18 & 28 & 0 & 0 \\
\hline Total & 729 & 357 & 232 & 117 & 23 \\
\hline
\end{tabular}

Source: Dataset

The two most enduring joint ventures were those between CEIAD-Columbia and DEAR-United Artists. In both cases the agreements served to strengthen preexisting relationships that dated back a number of years. ${ }^{78}$ With the re-opening of the Italian market after the Second World War, Columbia chose not to reestablish distribution offices in Italy, but rather to distribute its pictures through CEIAD (Cinematografica Edizioni Internazionali Artistiche Distribuzione). Having acted as the exclusive distributor of Columbia films in Italy for a decade, CEIAD entered into joint distribution with its long standing American partner in the mid-1950s, and as we see from table 3, the relationship was still going strong in the 1970s. United Artists had ceased direct distribution of its films in Italy in 1932, and in the post-war years distributed in Italy exclusively through DEAR (Distribuzione Edizioni Associate Rizzoli), and its predecessor firm DAI (Distribuzione Associata Internazionale). As we see from table 3, the exclusive distribution agreement was developed into a joint venture in 1962, and as with the CEIAD-Columbia partnership, this lasted into the 1970s.

The year 1962 also saw DEAR enter into a joint venture with Twentieth CenturyFox. Rather than building on an established relationship however, this agreement marked a strategic decision on the part of Fox to distribute in partnership with a local firm rather than operating through a wholly owned subsidiary - which had been always previously their mode of operation in Italy. The joint venture was not a complete merger of the two firms' distribution businesses in Italy, as DEAR maintained a separate joint venture with United Artists, and when the partnership broke down in 1967 Fox resumed direct distribution of its own pictures in Italy. Following the termination of the partnership with Fox, DEAR entered into a similar arrangement with Warner Bros., although this was even shorter lived.

${ }^{78}$ Annuario del cinema italiano e audiovisivi 1953-1957. 
Correspondence files in the Warner Bros. archive reveal that this American firm had been in discussion with several leading Italian distributors regarding the pooling of distribution operations in the early 1960s. Following the collapse of an agreement with the producer-distributor Dino De Laurentis, which had got as far as receiving approval from the Warner Bros. Board of Directors, the company embarked on detailed negotiations to reach a similar arrangement with the distributor Euro International in April 1963.79 Euro, according to Warners' Italian manager, had also previously been in discussion with Twentieth CenturyFox and Universal. ${ }^{80}$ The available archival evidence, therefore, would appear to suggest a considerable interest on the part of US distributors in aligning their Italian distribution operations with local firms, even if many of the proposed alliances never made it to completion.

Clearly not all US firms were able to establish joint distribution arrangements with domestic Italian companies, and where such agreements were reached, some were more durable than others. Even where US firms operated through wholly owned subsidiaries, however, it was still possible for those subsidiaries to acquire the distribution rights of Italian films. Warner Bros., for example, had an agreement to distribute the films of the Italian producer Galatea Pictures in the early 1960s, while Paramount made agreements of this type with some of the major Italian producer-distributors such as Lux and Dino De Laurentiis at various points during our period. The incentive for Italian producers to enter into such agreements was the potential for improved international distribution of their pictures. Table 4 shows which US firms were most successful in securing the distribution rights to domestically produced films in the Italian market.

While the distribution portfolios of all US firms were dominated by American productions, we do see some quite significant differences between these companies in the extent to which they handled domestic product. Paramount and Warner Bros. each distributed 55 Italian films during the period, whereas Universal released just six. Paramount's agreements with Lux ${ }^{81}$ and, more importantly, Dino De Laurentis meant that a significant proportion of the Italian films it distributed were high profile productions with box office earnings that placed them in the top revenue category. Fewer than one in five of the films released by Paramount were Italian productions, yet these constituted almost two-fifths of its highest earning films. Of all the Italian films released by US distributors that made it into the top revenue category, half were distributed by Paramount (and none by Fox or Universal). Paramount and Universal merged their international distribution businesses in 1970, and the resulting organisation, Cinema International Corporation (CIC), was responsible for the release of several more high profile Italian films in 1970 and 1971. Both MGM and Warner Bros were able to secure distribution of similar numbers of Italian films as Paramount, but the vast majority of these pictures fell into the lower revenue categories.

\footnotetext{
${ }^{79}$ Greenberg to Orlandi, 5 April 1963, "Italy Office" 16520B, WBA.

80 Orlandi to Abeles, 27 March 1963, "Italy Office” 16520B, WBA.

81 "Il primo congresso Paramount dopo la fusione Lux-Paramount", in Giornale dello Spettacolo, July $1^{\text {st }} 1962$.
} 
Table 4: Breakdown of films released in the Italian first run market by American distributors, 1957-71

\begin{tabular}{|c|c|c|}
\hline & $\begin{array}{c}\text { Highest earning } \\
\text { films } \\
\text { >L.150million }\end{array}$ & All films \\
\hline \multicolumn{3}{|l|}{$20^{\text {th }}$ Century-Fox } \\
\hline US productions & 13 & 185 \\
\hline ITA/US productions & 0 & 1 \\
\hline ITA productions & 0 & 9 \\
\hline Other foreign productions & 1 & 23 \\
\hline \multicolumn{3}{|l|}{ CIC } \\
\hline US productions & 4 & 27 \\
\hline ITA/US productions & 0 & 1 \\
\hline ITA productions & 4 & 8 \\
\hline Other foreign productions & 0 & 0 \\
\hline \multicolumn{3}{|l|}{ MGM } \\
\hline US productions & 19 & 317 \\
\hline ITA/US productions & 5 & 10 \\
\hline ITA productions & 2 & 40 \\
\hline Other foreign productions & 0 & 28 \\
\hline \multicolumn{3}{|l|}{ Paramount } \\
\hline US productions & 16 & 218 \\
\hline ITA/US productions & 0 & 0 \\
\hline ITA productions & 10 & 55 \\
\hline Other foreign productions & 2 & 21 \\
\hline \multicolumn{3}{|l|}{ Universal } \\
\hline US productions & 20 & 241 \\
\hline ITA/US productions & 1 & 1 \\
\hline ITA productions & 0 & 6 \\
\hline Other foreign productions & 1 & 15 \\
\hline \multicolumn{3}{|l|}{ Warner Bros. } \\
\hline US productions & 19 & 201 \\
\hline ITA/US productions & 0 & 0 \\
\hline ITA productions & 4 & 55 \\
\hline Other foreign productions & 0 & 19 \\
\hline
\end{tabular}

Source: Dataset

If Paramount was able to distinguish itself in the Italian market by securing access to high profile films by leading domestic producers, MGM was more active than other US firms in co-producing with Italian companies. Of all the films released in Italy by US distributors in this period, just 13 were Italian-American co-productions, and of these no less than 10 were distributed by MGM. As we have already noted, these American-Italian collaborations were often highly popular with Italian audiences, and half of MGM's local co-productions made it into the highest revenue bracket. Both Paramount and MGM, through their agreements with domestic film producers in Italy, were thus able to construct film portfolios which contained a significant proportion of content with a distinct local flavour. 
Table 5: Breakdown of films released in the Italian first run market by ItalianAmerican distributors, 1957-71

\begin{tabular}{lcr}
\hline & $\begin{array}{c}\text { Highest earning } \\
\text { films } \\
\text { >L.150million }\end{array}$ & All films \\
\hline CEIAD-Columbia & 20 & 233 \\
US productions & 1 & 4 \\
ITA/US productions & 8 & 54 \\
ITA productions & 0 & 65 \\
Other foreign productions & & \\
DEAR-United Artists & 15 & 147 \\
US productions & 2 & 5 \\
ITA/US productions & 2 & 27 \\
ITA productions & 8 & 52 \\
Other foreign productions & & \\
DEAR-Fox & 8 & 69 \\
US productions & 0 & 0 \\
ITA/US productions & 2 & 27 \\
ITA productions & 0 & 21 \\
Other foreign productions & & \\
DEAR-Warner Bros. & 1 & 0 \\
US productions & 0 & 7 \\
ITA/US productions & 1 & 2 \\
ITA productions & 0 & \\
Other foreign productions & & \\
\hline$\quad$ & & \\
\hline Source: Dataset & &
\end{tabular}

The distribution joint-ventures between US and Italian firms were also able to offer Italian exhibitors a mixed portfolio of films. As we see from table 5, CEIADColumbia was comparable with Paramount, both in terms of the volume of Italian films it distributed, and the proportion that fell into the top box-office revenue category. DEAR-United Artists distributed fewer high profile Italian films, but it was able to supplement these with the occasional Italian-US coproduction, as well as a much more regular supply of popular films from other parts of the world (including the series of James Bond movies). ${ }^{82}$ The DEAR-Fox joint venture provides an interesting comparison with Twentieth Century-Fox's direct distribution practices. The joint venture was operational for only 5 full years (out of 14) and therefore handled fewer films than Fox's wholly owned subsidiary, yet it released three times the number of Italian productions.

However, it is not apparent that this access to Italian pictures did much to boost the American distributor's fortunes. Ten per cent of the US films handled by DEAR-Fox fell into the top revenue category, yet the figure for its Italian films was just 7 per cent. This may provide part of the reason why Twentieth CenturyFox reverted to direct distribution towards the end of the 1960s.

82 Of the twenty highest earning film releases in our dataset, three were from the James Bond franchise: Thunderball (1965), Goldfinger (1964) and You Only Live Twice (1967). 


\section{Working towards insider status: the activities of distribution subsidiaries}

Entering into agreements with local film producers or distributors was clearly an attractive strategic option for US film companies in Italy. Deals with local production companies enabled firms like Paramount to offer audiences a regular supply of popular Italian-made films, and for MGM to release a series of ItalianAmerican productions. Distribution joint ventures involving Columbia and United Artists allowed these companies to maximise the exposure of their top earning films in the Italian market. But how did such alliances come about? It is one thing to recognise a commercial incentive for partnering with local firms, but pursuing such a strategy effectively requires an intimate understanding of local business practices and a high degree of integration within local business networks. To borrow a concept from the strategic management literature, subsidiary firms need to possess "absorptive capacity" if they are to benefit from access to local knowledge or network connections. ${ }^{83}$ How then, did the distribution offices of US firms actually operate in practice?

The first observation we can make about the running of American distribution subsidiaries in Italy is that they were typically headed by local Italian managers. A survey of the 'industry personnel' pages of the Film Daily Yearbook provides the names of these managers, many of whom held their positions for long periods. The head of Paramount's Italian operations in the 1960s was Pilade Levi, who had occupied this post since the late 1940s. Mario Zama, who had managed Warner Bros. distribution in Italy in the mid-1930s was still doing the same job twenty years later. Another Zama (Emanuele) headed Universal's Italian subsidiary from the 1940s until around 1960. The pages of the trade directories indicate that US firms did not rotate managers between different national territories. Managers appear to have been locally recruited and typically remained in Italy throughout their career. The trade directories do, however, offer some evidence that Italian managers occasionally moved between firms. When setting up their joint venture with Dear in 1962, for example, United Artists recruited the head of MGM's Italian subsidiary to lead the new enterprise. ${ }^{84}$ If US companies relied on local managers to run their Italian distribution offices, what was it that these managers did? What was the nature of their local knowledge, and how did they put it to use in the service of their American employers?

The distribution records held within the Warner Bros. archive provide a valuable insight into the routine functioning of foreign distribution subsidiaries in the 1950s and 1960s. The head of Warner's Italian distribution for much of this period was Umberto Orlandi, and extensive correspondence between Orlandi and his superiors in New York has survived. These records point to four broad areas in which the company drew on the local knowledge of its Italian manager. In each case it would be difficult to imagine an American expatriate being easily able to perform an equivalent role.

\footnotetext{
${ }^{83}$ Cohen, Levinthal, "Absorptive capacity".

${ }^{84}$ Film Daily Yearbook, multiple years.
} 
The first of these areas was Orlandi's accumulated knowledge of local audience tastes and preferences. One of the tasks of local distribution subsidiaries was to supply head office with estimates for final gross billings for all pictures, and to update these estimates regularly as films progressed through their distribution runs. (Failure to do this would result in a firm rebuke from the Group Treasurer) ${ }^{85}$ By closely following audience responses, managers like Orlandi developed a keen sense of market trends and were well placed to recommend which films would be most suitable for release in the Italian market, and to develop appropriate release strategies. Warner's decision not to acquire distribution rights to the 1960 film Carthage in Flames (dir. Carmine Gallone) was taken on Orlandi's advice that "the picture has not got the quality that warrants this type of investment." ${ }^{\text {" } 6}$ In cases where distribution deals for Italian pictures were agreed, Orlandi also made recommendations as to whether Warner Bros. should also seek international distribution rights. ${ }^{87}$ As well as casting judgement on the likely popular appeal of Italian pictures, Orlandi could also influence the marketing of American films. In the case of the 1961 drama Fanny (dir. Josh Logan) he warned against releasing the film under this title in the light of the poor reception of an earlier Italian production of the same name. ${ }^{88}$ Foreign distributors that lacked detailed local knowledge were at risk of committing quite serious blunders in the marketing of locally produced films. At one private screening of preliminary footage for a forthcoming film, for example, foreign distributors raised questions about dubbing - not realising that the actors were speaking in a widely understood Roman dialect. ${ }^{89}$

It was not just Orlandi's knowledge of local audience preferences that was sought by his head office superiors, but his understanding of local regulations and their interpretation. He often fielded requests from New York executives seeking clarity on very specific questions relating to matters such as dubbing policy, or the necessity of producing certificates of nationality for individual films. ${ }^{90}$ Without the ability to obtain quick answers to routine questions such as these, the operational efficiency of US distributors would have been greatly undermined.

A third area where the knowledge and expertise of local managers was essential was in conducting negotiations with other domestic firms. It was Orlandi, for example, who led negotiations with Dino del Laurentis and Euro International about potential distribution joint ventures. While decisions about whether to go ahead with such deals were taken at a higher level, senior executives in New York were heavily reliant on Orlandi's own accounts of the negotiations in reaching their judgements. ${ }^{91}$ While major strategic decisions such as the creation of a new distribution partnership were closely monitored by the New York head

\footnotetext{
85 O’Sullivan to Orlandi, 15 August 1961, Box 16613B, WBA.

86 Cohen to Orlandi, 25 August 1959, Box 16519A, WBA.

87 'Italy - Co-Production Deals', 10 January 1958, Box 16519A, WBA.

88 Cohen to Abeles, 18 August 1961, Box 16613B, WBA.

89 Della Casa, de Hadeln, Capitani coraggiosi: produttori italiani 1945-1975, p. 197.

90 Greenberg to Orlandi, 19 August 1963; Greenberg to Orlandi, 6 March 1961, Box 16519A, WBA.

91 Orlandi to Abeles, 27 March 1963, 11 April 1963, 19 April 1963, Box 16520B, WBA.
} 
office, Orlandi had considerably more leeway when negotiating with Italian producers about distribution rights to individual films.

Finally, and perhaps most significantly, Italian managers provided US firms not just with access to local knowledge, but also to local networks. Orlandi, for example, was a prominent member of the Italian distributors organisation ANICA. In the late 1950s he played an important role in discussions between ANICA and the body representing film exhibitors (AGIS) about the organisation of distribution practices in Italy, well before any proposals were put to the managers of other American firms. ${ }^{92}$ Perhaps the clearest evidence of how Orlandi sought to build and strengthen his informal ties with key figures in the Italian industry comes from frequent requests to head office to authorise payment of irregular expenditures. Here is a typical example from December 1954:

"In the course of our daily struggle to obtain censorship, visas, importation and exportation permits as well as deblockments, we have received many favours from some gentlemen whose names you know through our correspondence and from whom we expect even more help in the future, so that we cannot let the approaching holidays pass without presenting them with some substantial gift. I therefore am asking your kind authorisation to spend for this purpose the following sums:

L.100,000 - Dr. Gianni de Tommasi, Censorship L.100,000 - Dr. Tommaso Rosa, Ministry of Foreign Trade deblockments, importation, exportation.

L.70,000 - Dr. Benito Orta, Presidency of the Council, importation and exportation.

I am sure you will understand my necessity in this matter for which I am counting on your warm helping hand."93

In the same year Orlandi requested (and was granted) permission to spend L.50,000 on a wedding present for the daughter of a prominent exhibitor in Genoa who at the time held the presidency of AGIS. ${ }^{94}$ Similar requests were made (and granted) to contribute to wedding celebrations, obituary notices or Christmas gifts for a range of figures in the industry (usually prominent exhibitors) with the amount of expenditure broadly reflecting the importance of the individual involved. ${ }^{95}$ Occasionally requests were made in the other direction, as when an important New York exhibitor visited Rome with his wife to celebrate their wedding anniversary. On this occasion Orlandi was asked to "extend to Mr. Frisch and his wife the usual courtesies." 96 While the practice of keeping on good terms with important industry partners would have been widespread across different business cultures, the way in which this was done

\footnotetext{
92 Orlandi to Hummel, 18 January 1957; Copy of letter dated 24 January 1957 from MPEAA/Rome, Box 16519A, WBA.

93 Orlandi to Hummel, 14 December 1954, Box 16682B, WBA.

94 Orlandi to Holenstein, 24 May 1954, Box 16682B, WBA.

95 Orlandi to Holenstein, 19 September 1958; Orlandi to Greenberg, 26 September 1961, Box 16682B, WBA.

96 The 'usual courtesies' would have involved the sort of hospitality that was extended to visiting film stars, such as delivery of a bouquet of flowers to their hotel, and use of a company car. See O'Sullivan to Orlandi, 3 August 1961, Box 16681B, WBA.
} 
clearly varied between countries where different institutions or "rules of the game" were in place. Institutional weaknesses have been identified as a key factor shaping the evolution of the Italian economy since unification, in particular the limited development of big business. ${ }^{97}$ Scholars have also pointed to inefficient institutions as part of "a wider picture of regulatory failure that may incentivise borderline, if not illegal, behaviours". ${ }^{98}$ Among advanced industrialised countries, Italy has been among the most susceptible to encroachment from the so-called "shadow economy". ${ }^{99}$ As far as the cinema industry was concerned, informal ties have always played an important role and gift practices appear to have been quite common.100 Local managers in Italy, already embedded within informal networks and familiar with local business practices, were much better placed than expatriates to work towards a position of "insidership" within this business community.

\section{Conclusions}

While the cultural impact of Hollywood entertainment on post-war Italian film audiences has been the subject of detailed historical investigation, ${ }^{101}$ this article has been the first to examine how American film distributors adapted to the Italian market. Italy, by the 1960s, constituted one of the largest motion picture markets outside the United States, and thus accounted for a significant proportion of Hollywood's foreign earnings. This was at a time when US domestic cinema attendance was in decline and foreign markets were an increasingly important source of revenue for American distributors. The article has sought to demonstrate that as well as being an important market for US film distributors, it was also a highly competitive one. The market share held by American films declined throughout the period in the face of a resurgent Italian production sector, and while some Hollywood films continued to hold a strong popular appeal, these were outnumbered by popular Italian pictures for most of the 1960s. As such, there was every incentive for US firms to take on a distinctly more Italian character if they were to succeed in this valuable market.

But what did localisation actually involve for American film distributors? Was it enough for these firms simply to offer products that could be perceived as local by Italian audiences (i.e. acquire distribution rights to more Italian films); or did they genuinely need to think and behave like Italian firms in order to integrate into local business networks? Our investigation finds that both were important. Italian films accounted for a growing share of box office revenues throughout the period, and so access to these films was important if US distributors were to maintain their market position. Moreover, there were fiscal incentives for Italian

\footnotetext{
97 Colli, Rinaldi, "Institutions, Politics and the Corporate Economy”.

98 Di Martino, Vasta, “Happy 150th Anniversary Italy?”, 294.

${ }^{99}$ Schneider, Enste, "Shadow Economies", 80.

100 Archival evidence of such practices is not easy to be found and most of these anecdotes belong to oral narratives. During the 1930 s a quite common practice was the request for free cinema tickets or free cinema subscriptions made by prominent individuals (politicians or bank managers) to Italian exhibitors. See Nicoli, Non arte, ma scarpe, 248-9. Another typical practice was to recommend people for working in the technical or artistic cast in return of financing promises. For other anecdotes see Sanguineti, Il cervello di Alberto Sordi. Rodolfo Sonego e il suo cinema; Della Casa, Splendor. Storia (inconsueta) del cinema italiano.

101 Gennari, Post-War Italian Cinema; Faldini, Fofi, L'avventurosa storia del cinema italiano.
} 
exhibitors to preference the screening of domestic films over foreign ones, so distributors handling mainly foreign product were at a disadvantage. Our data also show, however, that US distributors were less effective than Italian ones in extending the screen time available to the most popular Hollywood pictures. The problem facing American distributors was not simply that their Hollywood product was seen as 'foreign' by Italian audiences who rejected it in favour of something more to their taste. Rather, it was one of persuading first run cinema exhibitors to allow the most popular of their films extended screen runs. We can, therefore, identify two distinct aspects to the localisation strategies being pursued by US distributors. The first can be thought of as a classic business-toconsumer marketing strategy, whereby US firms sought access to more locally produced content that Italian audiences would not necessarily identify as American. The second involved business-to-business interactions between US distributors and local contacts, in which American firms needed to demonstrate a much deeper understanding of local business systems and practices.

Different US firms responded to the first of these challenges in different ways. Paramount was particularly effective in reaching agreements with leading Italian producers, providing it with the right to distribute a number of popular Italian films. MGM was more notable for its engagement in joint productions with established Italian producers, enabling it to secure distribution rights to some of the most popular Italian-American films of the period. Columbia and United Artists pursued an alternative path of establishing distribution joint ventures with local firms (a strategy also briefly followed by Twentieth Century-Fox and Warner Bros.)

In order to explore the second, and more complex, aspect of localisation the article has delved deeper into corporate archives to shine a light on the more routine operational practices of their Italian distribution subsidiaries. Here we arrive at the "front line" at which American firms engaged most directly with the domestic Italian cinema industry. The staff working in these offices might be thought of as the "foot soldiers" of Americanization - but our evidence suggests that that their role was as much one of educating New York executives about the daily realities of the local business environment as it was about spreading the influence of the American way of life. Certainly, without the detailed knowledge of these local Italian managers, and access to their networks of local business contacts, it would have been difficult for American firms to build the sorts of relationships with local producers or distributors on which their localisation strategies were based. The closer we get to the mundane operational realities of these American firms in Italy, the more clearly can we see their attempts to leverage relationships and contacts to embed themselves in the local market. We do not claim that US distribution subsidiaries fully succeeded in achieving insider status in the Italian film industry of the 1960s, but our evidence shows that in this post-studio era these American firms found it necessary to work towards such a goal. 
Bibliography of works cited

Books

Abo, Tetsuo, ed., Hybrid Factory, New York: Oxford University Press, 1994.

ANICA (Associazione Nazionale Industrie Cinematografiche e Affini), Venti anni dell'ANICA per il cinema italiano 1944-1964, Roma, Tipografica Editrice Romana, 1964, 12-14.

Balduini, Consuelo, Miracoli e boom. L'Italia dal dopoguerra al boom economico nell'opera di Cesare Zavattini, Reggio Emilia, Aliberti, 2013.

Balio, Tino, United Artists: The Company Built by the Stars, Madison, Wi., University of Wisconsin Press, 1976.

Barca, Fabrizio, ed., Storia del capitalismo italiano dal dopoguerra a oggi, Roma, Donzelli, 1997.

Bartlett, Christopher and Ghoshal, Sumantra, Managing Across Borders: The Transnational Solution, Boston, Harvard Business School Press, 1989.

Belcampo, Nunzioclaudio, L'Italia entra nel miracolo economico in bicicletta e ne esce in automobile, Roma, Prospettiva Editrice, 2008.

Bocca, Giorgio, Miracolo all'italiana, Roma, Avanti, 1962.

Bondanella, Peter, Italian Cinema from Neorealism to the Present, New York, NJ, Continuum, 1983, 142-144.

Bonin, Hubert, de Goey, Ferry, eds., American Firms in Europe, 1880-1980:

Strategy, Identity, Perception and Performance, Geneva, Swiss, Droz, 2009.

Brunetta, Gian Piero, Storia del cinema italiano, Vol. 3, Roma, Editori Riuniti, 1993.

Brunetta, Gian Piero, The History of Italian Cinema: A Guide to Italian Film from its Origins to the Twenty-First Century, Princeton, Princeton University Press, 2003.

Burke, Frank, and Marguerite Valler, eds., Federico Fellini: Contemporary Perspective, Toronto, Buffalo, London, University of Toronto Press, 2002.

Cardini, Antonio, Il miracolo economico italiano 1958-1963, Bologna, Il Mulino, 2006.

Casetti, Francesco, Mosconi, Elena, Riti e ambienti del consumo cinematografico (1900-1950) Roma, Carocci, 2006.

Casper, Drew, Postwar Hollywood 1946-1962, Oxford, UK, Blackwell, 2007. 
Castronovo, Valerio, L'Italia del miracolo economico,Roma-Bari, Laterza, 2010.

Castronovo, Storia economica d'Italia. Dall'Ottocento ai giorni nostri, Torino, Einaudi, 1995.

Corsi, Barbara, Con qualche dollaro in meno. Storia economica del cinema italiano, Roma, Editori Riuniti, 2001, 37-42.

Crainz, Guido, Storia del miracolo italiano. Culture, identità, trasformazioni fra anni cinquanta e sessanta, Roma, Donzelli, 2003.

Crainz, Il paese mancato. Dal miracolo economico agli anni ottanta, Roma, Donzelli, 2003.

D'Amico, Masolino, La commedia all'italiana. Il cinema comico in Italia dal 1945 al 1975, Milano, Il Saggiatore, 2008.

D'Apice, Carmela, L'arcipelago dei consumi. Consumi e redditi delle famigle in Italia dal dopoguerra ad oggi, Bari, De Donato, 1981.

De Vany, Arthur, Hollywood Economics: How Extreme Uncertainty Shapes the Film Industry, Abingdon, UK, Routledge, 2004.

Della Casa, Stefano, de Hadeln Moritz, eds., Capitani coraggiosi: produttori italiani 1945-1975, Milano, Electa, 2003.

Della Casa, Splendor. Storia (inconsueta) del cinema italiano, Roma-Bari, Laterza, 2013.

Diena, Leone, Gli uomini e le masse. Saggio di ricerca su atteggiamenti di vita e di lavoro in una grande città industriale, Torino, Einaudi, 1960.

Djelic, Marie-Laure, Exporting the American Model. The Postwar Transformation of European Business, Oxford, UK, Oxford University Press, 2001.

Ellwood, David and Rob Kroes, eds. Hollywood in Europe: Experiences of a cultural hegemony, Amsterdam: Amsterdam University Press, 1994.

Faldini, Fofi, eds., L'avventurosa storia del cinema italiano raccontata dai suoi protagonisti. 1935-1959, Milano, Feltrinelli, 1979.

Fanchi, Mariagrazia, Mosconi, Elena, eds., Forme di consumo e pubblici del cinema in Italia 1930-1960, Venezia, Marsilio, 2002.

Ferrau, Alessandro, Annuario del cinema italiano \& audiovisivi 1953-1957, Centro di studi di cultura, promozione e diffusione del cinema, Roma, 1958. 
Florida, Richard, The rise of the creative class, Saint Louis, MO, Turtleback Books, 2003.

Foot, John, Milano dopo il miracolo: biografia di una città, Milano, Feltrinelli, 2003.

Forbes, Jill and Street, Sarah, European Cinema: An Introduction, Basingstoke, Palgrave, 2000.

Gennari, Daniela, Post-War Italian Cinema: American Intervention, Vatican Interests, Abingdon, UK, Routledge, 2009, 6-8.

Ginsborg, Paul, Storia d'Italia dal dopoguerra a oggi. Società e politica 1943-1988, Torino, Einaudi, 1989.

Glancy, Mark, When Hollywood Loved Britain: the Hollywood 'British' film, 19391945, Manchester, UK, Manchester University Press, 1999.

Gomery, Douglas, The Hollywood Studio System: A History, London, UK, BFI, 2005.

Gorgolini, Luca, L'Italia in movimento. Storia sociale degli anni Cinquanta, MilanoTorino, Mondadori, 2013.

Grande, Maurizio, La commedia all'italiana, Roma, Bulzoni, 2003.

Guback, Thomas, The international film industry: Western Europe and America since 1945, Bloomington, IN., Indiana University Press, 1969.

Gundle, Stephen, Communism and Cultural Change in Postwar Italy, Cambridge, UK, Cambridge University Press, 1984.

Higson, Andrew, and Richard Maltby, eds., "Film Europe" and "Film America": Cinema, Commerce and Cultural Exchange 1920-1939, Exeter, UK, University of Exeter Press, 1999.

Hymer, Stephen, the international operations of national firms: a study of direct foreign investments, Cambridge, MA, MIT Press, 1976.

Howkins, John, The creative economy. How people make money from ideas, London, UK, Penguine Books, 2003.

Jarvie, Ian, Hollywood's Overseas Campaign: The North Atlantic Movie Trade, 1920-1950, Cambridge, UK, Cambridge University Press, 1992.

Jewell, Richard, RKO Radio Pictures: A Titan is Born, Berkeley, CA, University of California Press, 2012.

Jones, Geoffrey, Multinationals and Global Capitalism: From the Nineteenth to the Twenty-first Century, Oxford, UK, Oxford University Press, 2005. 
Kindleberger, Charles, American Business Abroad: Six lectures on direct investments, New Haven and London, Yale University Press, 1969.

Kipping Matthias, Bjarnar, Ove, eds., The Americanisation of European Business, London: Routledge, 2002.

Kuisel, Richard, Seducing the French. The Dilemma of Americanization, Berkeley • Los Angeles • Oxford, università of California Press, 1993.

Lanaro, Silvio, Storia dell'Italia repubblicana. Dalla fine della Guerra agli anni novanta, Venezia, Marsilio, 1992.

Lanzoni, Remi Fournier, Comedy Italian Style: The Golden Age of Italian Film Comedies, London, Continuum, 2008.

Lasky, Betty, RKO: The Biggest Little Major of them All, Santa Monica, Ca., Roundtable, 1989.

Lev, Peter, The Euro-American Cinema, Austin, TX, The University of Texas Press, 1993, 18-19.

Luzzatto Fegiz, Pierpaolo, Il volto sconosciuto dell'Italia, Roma, Giuffre, 1966.

Mafai, Miriam, Il sorpasso: gli straordinari anni del miracolo economico 19581963, Milano, Mondadori, 1997.

Morcellini, Mario, De Nardis, Paolo, eds., Società e industria culturale in Italia, Roma, Meltemi, 1998.

Nicoli, Marina, Ph. D. Thesis, Non arte, ma scarpe. Il cinema italiano tra economia e cultura nel primo novecento, Università Bocconi, 2009.

Nowell-Smith, Geoffrey, Making Waves: New Cinemas of the 1960s, London, Continuum, 2008, 152-162.

Pintus, Pietro, ed., La commedia all'italiana. Parlano i protagonisti, Roma, Gangemi Editore, 1985.

Prahalad, Coimbatore and Doz, Yves, The Multinational Mission: Balancing Local Demands and Global Vision, New York, The Free Press, 1987.

Quaglietti, Lorenzo, Storia economico-politica del cinema italiano 1945-1980, Roma, Editori Riuniti, 1980.

Quaglietti, Il cinema Italiano nel dopoguerra: leggi produzione, distribuzione, esercizio, Mostra Internazionale del Nuovo Cinema, Pesaro, 1974. 
Reich, Jacqueline, Beyond the Latin Lover: Marcello Mastroianni, Masculinity and Italian Cinema, Bloomington, IN, Indiana University Press, 2004.

Sanguneti, Tatti, Il cervello di Alberto Sordi. Rodolfo Sonego e il suo cinema, Milano, Adelphi, 2015.

Saunders, Thomas, Hollywood in Berlin: American Cinema and Weimar Germany, Berkeley, CA, University of California Press, 1994.

Segrave, Kerry, American Films Abroad: Hollywood's Domination of the World's Movie Screens, Jefferson, NC, McFarland, 1997.

Scott, Allen, On Hollywood: The place, The industry, Princenton, N.J., Princenton University Press, 2005.

Small, Pauline, Sophia Loren: Moulding the Star, Bristol-Chicago, Intellect Book, 2009.

Sorlin, Pierre, Italian National Cinema 1896-1996, London, Routledge, 1996, 115 143.

Spinazzola, Vittorio, Cinema e pubblico. Lo spettacolo filmico in Italia 1945-1965, Milano, Bompiani, 1974.

Stokes, Melvin, Maltby, Richard, Hollywood Abroad: Audiences and Cultural Exchange, London, UK, BFI, 2007.

Thompson, Kristine, Exporting Entertainment: America in the world film market 1907-1934, London, UK, BFI, 1985.

Trumpbour, John, Selling Hollywood to the World: US and European Struggles for Mastery of the Global Film Industry, 1920-1950, Cambridge, UK, Cambridge University Press, 2002.

Van der Wee, Herman, L'economia mondiale tra crisi e benessere (1945-1980), Milano, Hoepli, 1989.

Vernon, Raymond, Sovereignty at Bay: the multinational spreadof U.S enterprises, London, UK, Longman, 1971

Wagstaff, Christopher, Italian Neorealist Cinema: An Aesthetic Approach, Toronto, University of Toronto Press, 2007, 417.

Waterman, David, Hollywood's road to riches, Cambridge, MA, Harvard University Press, 2005.

Wilkins, Mira, The Maturing of Multinational Enterprise: American Business Abroad from 1914 to 1970, Cambridge, MA, Harvard University Press, 2013. 
Williams, Kevin, European Media Studies, London, Hodder Arnold, 2005.

Wood, Mary, Italian Cinema, Oxford, Berg, 2005.

Zeitlin, Jonathan, Herrigel, Gary, eds., Americanization and Its Limits. Reworking US Technology and Management in Post-War Europe and Japan, New York: Oxford University Press, 2000.

\section{Articles and chapters}

Aksoy, Asu and Kevin Robins, "Hollywood for the 21st century: global competition for critical mass in image markets", Cambridge Journal of Economics, Vol. 16, no. 1, (1992): 1-22.

Baik, Bok, Jun-Koo Kang, Jin-Mo Kim and Joonho Lee, "The liability of foreignness in international equity investments: evidence from the US stock market." Journal of International Business Studies, 44, no. 4 (2013): 391-411.

Barbiellini Amidei, Federico, Cantwell, John, and Anna Spadavecchia, "Innovation and Foreign Technology." In The Oxford Handbook of the Italian Economy Since Unification, edited by Gianni Toniolo, 378-416. Oxford, Oxford University Press, 2013.

Barlett, Christopher and Sumantra Goshal, "Tap your subsidiaries for global reach", Harvard Business Review, 64, no. 6 (1986): 87-94.

Bhanji, Zahra and Joanne Oxley, "Overcoming the dual liability of foreignness and privateness in international corporate citizenship partnerships." Journal of International Business Studies, 44, no. 4 (2013): 290-311.

Birkinshaw, Julian and Neil Hood, "Multinational subsidiary evolution: capability and charter change in foreign-owned subsidiary companies." Academy of Management Review, Vol. 23, no. 4, (1998): 773-795.

Birkinshaw, Julian, Neil Hood and Stefan Jonsson, "Building Firm-Specific Advantages in Multinational Corporations: The Role of Subsidiary Initiative." Strategic Management Journal, 19, no. 3, (1998): 221-241.

Brunetta, Gian Piero, "The long march of American cinema in Italy: from fascism to the cold war." In Hollywood in Europe: Experiences of a Cultural Hegemony, edited by Ellwood, David and Rob Kroes, 139-154. Amsterdam: Amsterdam University Press, 1994.

Cantwell, John, and Ram Mudambi, "MNE competence-creating subsidiary mandates." Strategic Management Journal, 26, No.12, (2005): 1109-1128. 
Cohen, Wesley, and Daniel Levinthal, "Absorptive capacity: a new perspective on learning and innovation." Administrative Science Quarterly, 35, no. 1, (1990): 128-152.

Colli, Andrea, "Investing in a Developing Economy: US and European Direct Investments in Italy (1915-1970)." In American Firms in Europe, 1880-1980: Strategy, Identity, Perception and Performance, edited by Bonin, Hubert, and Ferry de Goey, 129-147. Geneva, Droz, 2009.

Colli, Andrea, and Alberto Rinaldi, "Institutions, Politics and the Corporate Economy." Enterprise and Society, 16, no. 2 (2015): 249-269.

Di Martino, Paolo, and Michelangelo Vasta, "Happy $150^{\text {th }}$ Anniversary Italy? Institutions and Economic Performance since 1861." Enterprise and Society, 16, no. 2 (2015): 291-312.

de Grazia, Victoria, "Mass Culture and Sovereignty: The American Challenge to European Cinemas, 1920-1960." The Journal of Modern History, 61, no. 1 (1989): 53-87.

Felice, Emanuele, and Giovanni Vecchi, "Italy's Modern Economic Growth, 18612011." Enterprise and Society, 16, no. 2 (2015): 225-248.

Garncarz, Joseph, "Hollywood in Germany: the role of American films in Germany, 1925-1990." In Hollywood in Europe: Experiences of a cultural hegemony, edited by Ellwood, David and Rob Kroes, 94-135. Amsterdam: Amsterdam University Press, 1994.

Gennari, Daniela Treveri, and John Sedgwick, "Memories in Context: The Social and Economic Function of Cinema in 1950s Rome." Film History, 27, no. 2 (2015): 76-104.

Gundle, Stephen, "L'americanizzazione del quotidiano. Televisione e consumismo nell'Italia degli anni Cinquanta”, Quaderni Storici, Vol. 21, no. 2, (1986): 561:594.

Hedlund, Gunnar, "The hypermodern MNC-A heterarchy?", Human Resource Management, Vol. 25, no. 1, (Spring 1986): 9-35.

Hennart, Jean-Francois, "Down with MNE-Centric Theories! Market Entry and Expansion as the Bundling of MNE and Local Assets." Journal of International Business Studies 40, no. 9 (2009): 1432-1454.

Johanson, Jan, and Jan-Erik Vahlne, "The Uppsala internationalization process model revisited: From liability of foreignness to liability of outsidership." Journal of International Business Studies, 40, no. 9 (2009): 1411-1431.

Kuisel, Richard, “Commentary:Americanization for Historians.” Diplomatic History, 24, no. 3, (2000): 509-515. 
Lubinski, Christina, "Liability of Foreignness in Historical Context : German Business in Pre-independence India (1880-1940)." Enterprise and Society, 15, no. 4, (2014): 722-758.

Meyer, Klaus, Ram Mudambi and Rajneesh Narula, "Multinational Enterprises and Local Contexts: The Opportunities and Challenges of Multiple Embeddedness." Journal of Management Studies, 48, no. 2, (2011): 235-252.

Mezias, John, "Identifying liabilities of foreignness and strategies to minimize their effects: the case of labor lawsuit judgments in the United States." Strategic Management Journal, 23, no. 3, (2002): 229-244.

Miskell, Peter, "Resolving the Global Efficiency Versus Local Adaptability Dilemma: US Film Multinationals in their Largest Foreign Market in the 1930s and 1940s." Business History, 51 no. 3 (2009): 426-444.

Miskell, Peter, "'Selling America to the World'? The rise and fall of an international film distributor in its largest foreign market: United Artists in Britain, 1927-1947", Enterprise and Society, 7, no. 4, (2006): 740-776.

Mudambi, Ram, and Pietro Navarra, "Is knowledge power? Knowledge flows, subsidiary power and rent-seeking within MNCs." Journal of International Business Studies, 35, no. 5, (2004): 385-406.

Narula, Rajneesh, "Exploring the Paradox of Competence-creating Subsidiaries: Balancing Bandwidth and Dispersion in MNEs." Long Range Planning, 47, nos. 12, (2014): 4-15.

Pellegrini, Guido, "Lo sviluppo strutturale dell'economia italiana dal dopoguerra al nuovo secolo." In Storia economica d'Italia, edited by Ciocca Pierluigi and Gianni Toniolo, Roma-Bari, Laterza, 2002.

Petri, Rolf, Storia economica d'Italia. Dalla Grande guerra al miracolo economico (1918-1963) Bologna, Il Mulino, 2002.

Pistoresi, Barbara, and Alberto Rinaldi, "Exports, Imports and Growth: New Evidence on Italy, 1863-2004." Explorations in Economic History, 49, no. 2 (2012): 241-254.

Schneider, Friedrich, and Dominik Enste, "Shadow Economies: Size, Causes and Consequences." Journal of Economic Literature, 38, no. 1 (2000): 77-114.

Scott, Allen, "A new map of Hollywood: the production and distribution of American motion pictures." Regional Studies, 36, no. 9, (2002): 957-975.

Scott, Allen, "Hollywood and the world: the geography of motion-picture distribution and marketing." Review of International Political Economy, 11, no. 1, (2004): 33-61. 
Sedgwick, John, Michael Pokorny and Peter Miskell, "Hollywood in the World Market: Evidence from Australia in the mid-1930s." Business History 56, no. 5 (2014): 689-723.

Sedgwick, John, and Michael Pokorny, "The risk environment of film-making: Warners in the Inter-War period." Explorations in Economic History, 35, no. 2 (1998): 196-220.

Stevens, Charles, and Oded Shenkar, "The Liability of Home: Institutional Friction and Firm Disadvantage Abroad." In Institutional Theory in International Business and Management edited by Tihanyi Laszlo, Timothy Devinney and Torben Pedersen. Bingley, UK: Emerald Group Publishing Limited, (2012): 127 - 148.

Storper, Michael, "Flexible specialisation in Hollywood: a response to Aksoy and Robins." Cambridge Journal of Economics, 17, no. 4 (1993): 479-484.

Storper, Michael, "The transition to flexible specialisation in the US film industry: external economies, the division of labour, and the crossing of industrial divides." Cambridge Journal of Economics, 13, no. 2, (1989): 273-305.

Storper, Michael and Susan Christopherson, "Flexible Specialization and Regional Industrial Agglomerations: The Case of the U.S. Motion Picture Industry." Annals of the Association of American Geographers, 77, no. 1, (March 1987): 104-117.

Strauss, Victor, “Foreign Distribution of American Motion Pictures." Harvard Business Review 8, no. 3 (1930): 307-315.

Swann, Paul, "The Little State Department: Washington and Hollywood's Rhetoric of the Post-war Audience." In Hollywood in Europe: Experiences of a cultural hegemony, edited by Ellwood, David and Rob Kroes, 176-196. Amsterdam: Amsterdam University Press, 1994.

Verbeke, Alain, Rob van Tulder and Liviu Voinea, "New policy challenges for European multinationals: a resource bundling perspective." In New Policy Challenges for European Multinationals, edited by Van Tulder, Rob, Alain Verbeke and Liviu Voinea, 1-27. Bingley, UK, Emerald Publishing, 2012.

Wagstaff, Christopher, "Italian Genre Films in the World Market." In Hollywood and Europe: Economics, Culture, National Identity, edited by Nowell-Smith, Geoffrey and Steven Ricci, 74-85. London, UK, BFI, 1998.

Wagstaff, Christopher, "A Forkful of Westerns: Industry, Audiences and the Italian Western." In Popular European Cinema, edited by Dyer, Richard and Ginette Vincendeau, 245-261. London, Routledge, 1992.

Zaheer, Srilata, and Elaine Mosakowski, "The dynamics of the liability of foreignness: a global study of survival in financial services." Strategic Management Journal, 18, no. 6, (1997): 439-463. 
Zaheer, Srilata, "Overcoming the liability of foreignness." Academy of Management Journal, 38, no. 2 (1995): 341-363.

\section{Archival sources}

Eddie Mannix ledger, held at the Margaret Herrick Library of the Academy of Motion Picture Arts and Sciences, Los Angeles.

William Schaefer ledger, held at the University of Southern California Film and Television Archives, Los Angeles.

Warner Bros. Archives. University of Southern California, School of Cinematic Arts, Los Angeles. 